Article

\title{
LC-ESI-QTOF/MS Profiling of Australian Mango Peel By-Product Polyphenols and Their Potential Antioxidant Activities
}

\author{
Danying Peng, Hafza Fasiha Zahid, Said Ajlouni, Frank R. Dunshea and Hafiz A. R. Suleria * \\ School of Agriculture and Food, Faculty of Veterinary and Agricultural Sciences, The University of Melbourne, \\ Parkville, VIC 3010, Australia; danyingp@student.unimelb.edu.au (D.P.); \\ zahidh@student.unimelb.edu.au (H.F.Z.); said@unimelb.edu.au (S.A.); fdunshea@unimelb.edu.au (F.R.D.) \\ * Correspondence: hafiz.suleria@unimelb.edu.au; Tel.: +61-470-439-670
}

Received: 25 September 2019; Accepted: 14 October 2019; Published: 18 October 2019

\begin{abstract}
Mango (Mangifera indica L.) is one of the most important fruits in the world. Mango peel is an important by-product that is rich in polyphenols and it could have high economic value if it is effectively utilized. Phenolic characterization is an essential step in the commercial utilization of mango peel by-products as food ingredients. Herein, qualitative and quantitative analyses of two Australian mango peel "Keitt" and "Kensington Pride" (K\&P) by-products were conducted while using liquid chromatography coupled to electrospray ionisation and quadrupole time of flight mass spectrometry (LC-ESI-QTOF/MS) and high-performance liquid chromatography coupled to photodiode array detector (HPLC-PDA). A total of 98 polyphenols compounds were tentatively identified in both Keitt peel and K\&P peel extracts, with greater concentrations of these compounds being detected in Keitt peel. The total phenolic content (TPC), total flavonoid content (TFC), and a total tannin content (TTC) were determined. The antioxidant activity of mango peel by-products was determined while using 2,2-diphenyl-1-picrylhydrazyl (DPPH) antioxidant assay, ferric reducing antioxidant power (FRAP) assay, and 2,2-azino-bis-3-ethylbenzothiazoline-6-sulfonic acid (ABTS) radical scavenging assay. Keitt peel contained higher concentrations of total phenolic compounds, flavonoids, and tannins and had higher antioxidant capacity in DPPH, FRAP, and ABTS assays as compared to K\&P peel. In HPLC-PDA quantification, the predominant phenolic compounds in Keitt peel and $\mathrm{K} \& \mathrm{P}$ peel were catechin $\left(62.32 \pm 0.01 \mathrm{mg} / \mathrm{g}_{\text {d.w. }}\right)$ and syringic acid $\left(17.78 \pm 0.01 \mathrm{mg} / \mathrm{g}_{\text {d.w }}\right)$.
\end{abstract}

Keywords: mango peels; polyphenols; LC-ESI-QTOF/MS; HPLC-PDA; antioxidant activity

\section{Introduction}

Mango (Mangifera indica L.) is one of the most important fruits in the world. In 2016, the production of mango around the world was over 48 billion tonnes, which is valued at nearly 30 thousand million US dollars, ranking fifth in the world fruit production [1]. Around 20\% of mango fruits are processed into various food products, such as puree, slices, canned, and others [2]. After processing, mango peel and mango seed are the major by-products, which are largely discarded as waste that ultimately become environment pollution. As mango peel makes up $7-24 \%$ of the total fruit weight and is rich in phenolic compounds [3], it could be an important and better source for ingredients for the functional food, nutraceutical, and pharmaceutical industries [4].

The main phenolic compounds in fruits include phenolic acids, flavonoids, tannins, anthocyanins, carotenoids, and tocopherols [5]. These phenolics can act as antioxidants, directly or indirectly preventing the formation of free radicals that contribute to many chronic health issues. Polyphenols can be extracted while using different organic solvents while their antioxidant potential can be varied depending upon the type of extraction, conditions, and the choice of solvents [6]. 
The antioxidant activity of phenolic compounds can be measured with different chemical assays, depending upon their mechanisms. These include (1) free radical scavenging methods that scavenge specific types of free radicals, such as 2,2-diphenyl-1-picrylhydrazyl (DPPH); (2) non-radical redox potential-based methods that are involved in reducing the capacity of antioxidant, such as ferric reducing antioxidant power (FRAP); (3) metal-chelating methods; and, (4) determination of total phenolic content (TPC) [7]. However, for extraction, identification, and structural characterization of these phenolic compounds, a combination of high-performance liquid chromatography (HPLC) coupled with electrospray ionization mass spectrometry (ESI-MS) is widely employed [5]. Previously, a few phenolic groups have been characterized in mango by-product while using HPLC/MS and these include ellagic acid and their derivatives, xanthones (principally mangiferin), and some major flavonoids [8,9]. Some of the common polyphenolic substances that are found in different mango varieties are mangiferin, (+)-catechin, quercetin-3-glucoside and quercetin-3-D-galactoside, kaempferol-3-O-glucoside, (-)-epicatechin, quercetin, and gallic acid [4]. Previously, different studies have been conducted globally to isolate and identify phenolic compounds in different mango by-products, but only a few have focussed on Australian mango by-products. "Keitt" and "Kensington Pride" (K\&P) are two common mangos that are produced in Australia.

Therefore, the objectives of this study were to (1) extract polyphenolic compounds from Australian "Keitt" and "Kensington Pride" mango by-products; (2) measure the total phenolic profile and their potential antioxidant activities and (3) characterize and quantify polyphenols in Australian mango peel extracts while using liquid chromatography coupled to electrospray ionisation and quadrupole time of flight mass spectrometry (LC-ESI-QTOF/MS) and high-performance liquid chromatography coupled to photodiode array detector (HPLC-PDA). The outcome of our research can provide important information for commercial utilisation of these mango by-products as ingredients of functional food, nutraceuticals, and pharmaceutical development.

\section{Materials and Methods}

\subsection{Chemical and Reagents}

Most of the chemicals that were used for extraction and characterization were analytical grade and purchased from Sigma-Aldrich (Castle Hill, NSW, Australia). Hydrated sodium acetate, methanol, hydrochloric acid, anhydrous sodium acetate, and glacial acetic acid were purchased from Thermo Fisher Scientific Inc. (Waltham, MA, USA). Sodium carbonate (anhydrous) was procured from Chem-Supply Pty Ltd. (Adelaide, SA, Australia) and sulfuric acid 98\% was from RCI Labscan (Rongmuang, Thailand). Folin and Ciocalteu's phenol reagent, gallic acid, quercetin, 2,4,6-tripyridyl-s-triazine (TPTZ), 2,2-diphenyl-1-picrylhydrazyl (DPPH), L-ascorbic acid, vanillin, hexahydrate aluminum chloride, ferric chloride, and 2,2'-azino-bis(3-ethylbenzothiazoline-6-sulphonic acid) (ABTS) were purchased from Sigma-Aldrich (Castle Hill, NSW, Australia). The reference standards for HPLC, including caffeic acid, chlorogenic acid, gallic acid, p-hydroxybenzoic acid, protocatechuic acid, syringic acid, catechin, epicatechin gallate, kaempferol, kaempferol-3-glucoside, quercetin, quercetin-3-galactoside, and quercetin-3-glucuronide, were purchased from Sigma-Aldrich (St. Louis, MO, USA). Water was deionized to reach a resistivity of $18.2 \mathrm{M} \Omega / \mathrm{cm}$ by Millipore Milli-Q Gradient Water Purification System (Darmstadt, Germany) and was filtered through a $0.22 \mu \mathrm{m}$ type Millipak ${ }^{\circledR}$ Express 20 Filter (Milli-Q, Darmstadt, Germany).

\subsection{Sample Preparation}

The mature fruits of two Australian mangoes, Keitt and Kensington Pride (K\&P), respectively, were obtained from a local retail market in Melbourne, Australia. The peels of 3-4 kg each mango variety were manually cleaned, removed cut into small pieces $(0.5 \times 1 \mathrm{~cm})$, and then frozen at $-20^{\circ} \mathrm{C}$ overnight, following by lyophilization at $-45^{\circ} \mathrm{C} / 50 \mathrm{MPa}$ while using the Dynavac engineering FD3 
Freeze Drier (Belmont, W.A., Australia) and Edwards RV12 oil sealed rotary vane pump (Bolton, England). The dried mango peels were ground to fine powder and stored at $-20^{\circ} \mathrm{C}$.

\subsection{Extraction of Phenolic Compounds}

Mango peel powder $(2.1 \pm 0.5 \mathrm{~g})$ was extracted with $20 \mathrm{~mL} \mathrm{30 \%} \mathrm{ethanol.} \mathrm{The} \mathrm{mixture} \mathrm{was}$ homogenized with the IKA Ultra-Turrax ${ }^{\circledR}$ T25 homogenizer (Rawang, Selangor, Malaysia) and subjected to shaking incubator (ZWYR-240, Labwit, Ashwood, VIC, Australia) at $120 \mathrm{rpm} 4{ }^{\circ} \mathrm{C}$ overnight. For antioxidant analysis, the peel extracts were centrifuged while using benchtop centrifuge (Hettich Rotina 380R, Tuttlingen, Germany) at $5000 \mathrm{rpm}$ for $15 \min \left(4^{\circ} \mathrm{C}\right)$. The filtrate was subsequently transferred and stored at $-20^{\circ} \mathrm{C}$. For HPLC and LCMS analysis, the peel extracts were filtered through a $0.45 \mu \mathrm{m}$ syringe filter (Thermo Fisher Scientific Inc., Waltham, MA, USA).

\subsection{Antioxidant Assays}

All of the antioxidant assays were performed by adopting the method of Gu et al. [10]. The data was measured by the Multiskan ${ }^{\circledR}$ Go microplate photometer (Thermo Fisher Scientific, Waltham, MA, USA). All of the tests were run in triplicate. The standard curves were created with $R^{2}>0.995$.

\subsubsection{Determination of Total Phenolic Content (TPC)}

The total phenolic content of the mango peel extracts was measured by the Folin-Ciocalteu method [11] with some modification. The sample extract $(25 \mu \mathrm{L})$ was mixed with $25 \mu \mathrm{L}$ Folin reagent solution (1:3 diluted with water) in a 96-well plate (Corning Inc., Corning, NY, USA), and then incubated at $25{ }^{\circ} \mathrm{C}$ for $5 \mathrm{~min}$. Afterwards, $200 \mu \mathrm{L}$ water and $25 \mu \mathrm{L} 10 \%(\mathrm{w} / \mathrm{w})$ sodium carbonate was added, followed by $1 \mathrm{~h}$ incubation at $25^{\circ} \mathrm{C}$. Absorbance was measured at $765 \mathrm{~nm}$ while using microplate reader. Each sample was tested in triplicate and quantification was based on the standard curve that was generated with $0-200 \mu \mathrm{g} / \mathrm{mL}$ gallic acid in ethanolic solution. Mango peel samples were expressed in $\mathrm{mg}$ gallic acid equivalents (GAE) per gram dry weight (d.w.) \pm standard deviation (SD).

\subsubsection{Determination of Total Flavonoid Content (TFC)}

The total flavanol content of the mango peels was estimated by $\mathrm{AlCl}_{3}$ colorimetric-based method [12], with some modification. The sample extract $(80 \mu \mathrm{L}), 80 \mu \mathrm{L} 2 \%$ aluminium chloride and $120 \mu \mathrm{L} 50 \mathrm{~g} / \mathrm{L}$ sodium acetate solution in water were added in a 96-well plate and then incubated at $25{ }^{\circ} \mathrm{C}$ for $2.5 \mathrm{~h}$. After incubation, the absorbance was measured at $440 \mathrm{~nm}$ in a microplate reader. Sample quantification was based on the standard curve that was generated with $0-50 \mu \mathrm{g} / \mathrm{mL}$ quercetin methanolic solution. Each sample was tested in triplicate and the mango peel samples were expressed in $\mathrm{mg}$ quercetin equivalents $(\mathrm{QE}) / \mathrm{g}_{\text {d.w. }}$.

\subsubsection{Determination of Total Tannin Contents (TTC)}

The tannin content of the mango peels was estimated by the colorimetric method [13], with some modification. $25 \mu \mathrm{L}$ of sample extract, $150 \mu \mathrm{L} 4 \%$ vanillin solution, and $25 \mu \mathrm{L} 32 \%$ sulfuric acid were mixed in a 96-well plate and then incubated at $25^{\circ} \mathrm{C}$ for $15 \mathrm{~min}$. After incubation, the absorbance was measured at $500 \mathrm{~nm}$ while using microplate reader. Sample quantification was based on the standard curve generated with $0-1000 \mu \mathrm{g} / \mathrm{mL}$ catechin methanolic solution. Each sample was tested in triplicate and mango peel samples were expressed in $\mathrm{mg}$ catechin equivalents $(\mathrm{CE}) / \mathrm{g}_{\text {d.w. }} \pm \mathrm{SD}$.

\subsubsection{2,2-Diphenyl-1-picrylhydrazyl (DPPH) Antioxidant Assay}

The radical scavenging activity of mango peels was measured by DPPH assay based on the method of Sogi, et al. [14], with some modification. $40 \mu \mathrm{L}$ sample was mixed with $260 \mu \mathrm{L}$ of $0.1 \mathrm{M}$ DPPH radical methanol solution in a 96-well plate, incubated for $30 \mathrm{~min}$ at $25^{\circ} \mathrm{C}$. After incubation, the absorbance was measured at $517 \mathrm{~nm}$ using microplate reader. Sample quantification was based on 
the standard curve that was generated with $0-50 \mu \mathrm{g} / \mathrm{mL}$ ascorbic acid aqueous solution. Each sample was tested in triplicate and the mango peel samples were expressed in $\mathrm{mg}$ ascorbic acid equivalents $(\mathrm{AAE}) / \mathrm{g}_{\text {d.w. }} \pm \mathrm{SD}$.

\subsubsection{Ferric Reducing Antioxidant Power (FRAP) Assay}

The ferric reducing capability of the mango peels was carried out while using the method based on Sogi, Siddiq, Greiby and Dolan [14], with some modification. The FRAP reagent was made fresh daily by mixing $300 \mathrm{mM}$ acetate buffer, $10 \mathrm{mM}$ TPTZ, and $20 \mathrm{mM}$ ferric chloride in a ratio of 10:1:1 (v/v/v). A $20 \mu \mathrm{L}$ sample extract and $280 \mu \mathrm{L}$ FRAP reagent were mixed in a 96-well plate and incubated at $37^{\circ} \mathrm{C}$ for $10 \mathrm{~min}$. After incubation, the absorbance was measured at $593 \mathrm{~nm}$ in a microplate reader. Sample quantification was based on the standard curve that was generated with $0-50 \mu \mathrm{g} / \mathrm{mL}$ ascorbic acid aqueous solution. Each sample was tested in triplicate and the mango peel samples were expressed in $\mathrm{mg} \mathrm{AAE} / \mathrm{g}_{\text {d.w. }} \pm \mathrm{SD}$.

\subsubsection{2,2-Azino-bis-3-ethylbenzothiazoline-6-sulfonic Acid (ABTS) Radical Scavenging Assay}

The ABTS antioxidant activity of the mango peels was determined while using the $\mathrm{ABTS}^{+}$radical cation decolourization assay with some modification [14]. $7 \mathrm{mM}$ ABTS and $140 \mathrm{mM}$ potassium persulfate solutions were mixed and then incubated in the dark for $16 \mathrm{~h}$ to generate an $\mathrm{ABTS}^{+}$stock solution. $\mathrm{ABTS}^{+}$solution was further diluted with ethanol to gain absorbance of $0.70 \pm 0.02$ at $734 \mathrm{~nm}$. A $10 \mu \mathrm{L}$ sample extract and $290 \mu \mathrm{L}$ prepared $\mathrm{ABTS}^{+}$solution was mixed in a 96-well plate, followed by an incubation at $25^{\circ} \mathrm{C}$ for $6 \mathrm{~min}$. After incubation, the absorbance was measured at $734 \mathrm{~nm}$ while using microplate reader. Sample quantification was based on the standard curve that was generated with $0-200 \mu \mathrm{g} / \mathrm{mL}$ ascorbic acid aqueous solution. Each sample was tested in triplicate and mango peel samples were expressed in $\mathrm{mg} \mathrm{AAE} / \mathrm{g}_{\text {d.w. }} \pm \mathrm{SD}$.

\subsection{Characterization of Phenolic Compounds by LC-ESI-QTOF/MS Analysis}

Polyphenol characterization was performed by adopting our previously published method of Gu et al. [10]. An Agilent 1200 series HPLC (Agilent Technologies, Santa Clara, CA, USA) coupled to an Agilent 6520 Accurate-Mass Q-TOF LC/MS (Agilent Technologies, Santa Clara, CA, USA) via an electrospray ionisation source (ESI) was used for the tentative identification and characterization of polyphenols. Separation was carried out on a Synergi Hydro-RP 80A, LC Column $(250 \mathrm{~mm} \times 4.6 \mathrm{~nm}$, $4 \mu \mathrm{m}$ ) (Phenomenex, Lane Cove, NSW, Australia) at a column temperature of $25^{\circ} \mathrm{C}$ and sample temperature of $10{ }^{\circ} \mathrm{C}$. Mobile phase A was $98 \%$ acetic acid in water and mobile phase B consisted of acetonitrile/water /acetic acid (100:1:99, v/v/v). The gradient program was carried out for $85 \mathrm{~min}$ by following conditions: $0 \mathrm{~min}, 90 \% \mathrm{~A}$ and $10 \% \mathrm{~B} ; 20 \mathrm{~min}, 75 \% \mathrm{~A}$ and $25 \% \mathrm{~B} ; 30 \mathrm{~min}, 65 \% \mathrm{~A}$ and $35 \% \mathrm{~B} ; 40 \mathrm{~min}, 60 \% \mathrm{~A}$ and $40 \% \mathrm{~B} ; 70 \mathrm{~min}, 45 \% \mathrm{~A}$ and $55 \% \mathrm{~B} ; 75 \mathrm{~min}, 20 \% \mathrm{~A}$ and $80 \% \mathrm{~B} ; 77-79 \mathrm{~min}$, $100 \% \mathrm{~B} ; 82-85 \mathrm{~min}, 90 \% \mathrm{~A}$ and $10 \% \mathrm{~B}$. The mobile phase flow rate was $0.8 \mathrm{~mL} / \mathrm{min}$, and the sample injection volume was $5 \mu \mathrm{L}$. Peak identification was performed in both negative and positive modes, and mass spectra in the $\mathrm{m} / \mathrm{z}$ range of 50-1300 were obtained. The mass spectrometry conditions were set, as follows: nitrogen gas temperature $300^{\circ} \mathrm{C}$ with the flow rate $5 \mathrm{~L} / \mathrm{min}$, sheath gas temperature $250{ }^{\circ} \mathrm{C}$ with the flow rate $11 \mathrm{~L} / \mathrm{min}$, nebulizer gas pressure $45 \mathrm{psi}$. The capillary and nozzle voltage were set at $3.5 \mathrm{kV}$ and $500 \mathrm{~V}$ respectively. Data acquisition and analysis were performed using Agilent LC-MS-QTOF Mass Hunter Data Acquisition Software Version B.03.01 (Agilent Technologies, Santa Clara, CA, USA).

\subsection{Polyphenol Quantification through HPLC-PDA Analysis}

The quantitative determination of targeted phenolic compound was performed by adopting the protocol of $\mathrm{Gu}$ et al. [10]. The quantification of phenolic compounds was carried out by the HPLC (Waters Alliance 2690, Chromatograph Separation Module) that was equipped with a photodiode array (PDA) detector (Model 2998, Waters). The same column and conditions maintained described 
in LC-ESI-QTOF/MS, except for sample injection volume of $20 \mu \mathrm{L}$. The UV detection was carried out at $280 \mathrm{~nm}, 320 \mathrm{~nm}$, and $370 \mathrm{~nm}$, with $1.25 \mathrm{scan} / \mathrm{s}$ (peak width $=0.2 \mathrm{~min}$ ) spectral acquisition rate. Thirteen polyphenol standards (Caffeic acid, chlorogenic acid, gallic acid, p-hydroxybenzoic acid, protocatechuic acid, syringic acid, catechin, epicatechin gallate, kaempferol, kaempferol-3-glucoside, quercetin, quercetin-3-galactoside, and quercetin-3-glucuronide), commonly present in mango products were selected for quantification purposes. Each polyphenol standard was diluted into seven different concentrations for generating calibration standard curves for quantification. Instrument control, data acquisition, and chromatography processing were performed while using the Empower Software (2010) (Shimadzu Scientific Instruments, Sydney, NSW, Australia).

\subsection{Statistics Analysis}

The results for chemical assays were expressed as mean \pm SD of three independent analyses. One-way analysis of variance (ANOVA) was used to verify the difference of antioxidant activity between the sample groups. Statistical significance of the difference was tested while using Tukey's HSD test at $p \leq 0.05$.

\section{Results and Discussion}

\subsection{Polyphenol Estimation (TPC, TFC and TTC)}

Mango peel is a rich source of polyphenols, such as phenolic acids and flavonoids, which have high antioxidant capacity [8]. The polyphenol content in mango peel was measured as TPC, TFC, and TTC (Table 1). These data shows that the polyphenol contents varied in both mango cultivars. Keitt peel had a significantly higher level of TPC and TFC than K\&P peel $(p \leq 0.05)$, while there was no significant difference in the tannin contents in both mango peel samples $(p \geq 0.05)$. Previously, Dorta, et al. [15] determined the TPC values (77-92 mg GAE $/ \mathrm{g}_{\text {d.w. }}$ ) in Keitt peel sample while using different solvents and drying methods, both solvent and drying methods effect overall polyphenol contents. They reported a slightly higher TFC in Keitt peel $\left(9.5 \pm 0.01 \mathrm{mg} Q \mathrm{QE} / \mathrm{g}_{\text {d.w. }}\right)$ samples while extracted with $50 \%$ ethanol at $25^{\circ} \mathrm{C}$.

Table 1. Polyphenol content and antioxidant activity detected in mango peels.

\begin{tabular}{ccc}
\hline Antioxidant Assays & Keitt Peel & K\&P Peel \\
\hline TPC (mg GAE/g) & $42.72 \pm 0.01^{\mathrm{a}}$ & $14.40 \pm 0.01^{\mathrm{b}}$ \\
TFC (mg QE/g) & $1.86 \pm 0.01^{\mathrm{a}}$ & $0.93 \pm 0.01^{\mathrm{b}}$ \\
TTC (mg CE/g) & $8.52 \pm 0.10^{\mathrm{a}}$ & $6.90 \pm 0.12^{\mathrm{b}}$ \\
DPPH (mg AAE/g) & $27.69 \pm 0.01^{\mathrm{a}}$ & $8.07 \pm 0.01^{\mathrm{b}}$ \\
FRAP (mg AAE/g) & $28.55 \pm 0.01^{\mathrm{a}}$ & $2.03 \pm 0.01^{\mathrm{b}}$ \\
ABTS (mg AAE/g) & $158.44 \pm 0.01^{\mathrm{a}}$ & $30.96 \pm 0.01^{\mathrm{b}}$ \\
\hline
\end{tabular}

The data are shown in mean \pm standard deviation $(n=3)$; the superscript letters $(a, b)$, indicate the means in a row with significant difference $(p<0.05)$ using a one-way analysis of variance (ANOVA) and Tukey's test. GAE stands for gallic acid equivalents; $Q E$ stands for quercetin equivalents; $C E$ stands for catechin equivalents, and AAE stands for ascorbic acid equivalents. Data of K\&P Peel and Keitt Peel is reported on a dry weight basis.

\subsection{Antioxidant Activities (DPPH, FRAP and ABTS)}

The antioxidant activity of mango peels was measured through DPPH, FRAP, and ABTS assay. These assays are widely used in testing the antioxidant capacity of food [7]. Table 1 shows that there are significant differences in the antioxidant activity between both mango cultivars. In general, the Keitt peel showed much higher antioxidant activity in all three antioxidant assays $(p \leq 0.05)$. The Keitt peel extract showed three times higher DPPH scavenging capacity as compared to K\&P. The DPPH assay is a single electron transfer-based method that measures the free radical scavenging ability of sample by detecting the DPPH radical capturing extent [16]. In the FRAP assay, Keitt peel extract showed significantly higher FRAP value as compared to K\&P. The FRAP assay is a typical single electron 
transfer-based method that measures the reducing power of antioxidants through reducing ferric ion $\left(\mathrm{Fe}^{+3}\right)$ into a ferrous ion $\left(\mathrm{Fe}^{+2}\right)$ [7]. The DPPH radical scavenging capacity and ABTS reducing power of Keitt peel extract has already been reported by Dorta, Lobo, and González [15] while computing with different standards.

In the ABTS assay, the ABTS radical scavenging capacity of both mango peels was significantly different with each other. Again, Keitt peel exhibited higher ABTS radical scavenging capacity (158.44 \pm $0.01 \mathrm{mg} \mathrm{AAE} / \mathrm{g}$ d.w.), which is five times higher than K\&P peel. The ABTS assay evaluates the sample ability to capture the radicals by measuring the ABTS radical scavenging level. The quenching of the $\mathrm{ABTS}^{+}$radical cation can be achieved either through directly reducing via electron donation or through radical quenching via hydrogen atom donation [7]. The ABTS radical scavenging capacity of Keitt peel has already been reported with a value of $380 \pm 4 \mathrm{mg} \mathrm{AAE} / \mathrm{g}_{\text {d.w. }}$. while using different solvent concentration [15]. López-Cobo, et al. [17] also reported the ABTS value of Keitt peel, which is $475.4 \pm$ $8.7 \mu \mathrm{M} \mathrm{FeSO}_{4} / \mathrm{mg}_{\text {d.w. }}$ using iron sulphate $\left(\mathrm{FeSO}_{4}\right)$ as the standard.

\subsection{Phenolic Compounds Profile by LC-ESI-QTOF/MS Analysis}

In the present work, a qualitative analysis of the phenolic compounds from the $30 \%$ ethanol extract of mango peels has been carried out while using LC-ESI-QTOF/MS analysis in negative and positive ionisation modes (Figure S1-Supplementary Materials). Table 2 shows the lists of all the compounds that were tentatively identified in both mango peels on the basis of their $\mathrm{m} / \mathrm{z}$ value from MS spectra in both negative and positive ionization mode $\left([\mathrm{M}-\mathrm{H}]^{-} /[\mathrm{M}+\mathrm{H}]^{+}\right)$, using an Agilent LC/MS MassHunter Qualitative Software and Personal Compound Database and Library (PCDL) with online database. Compounds having more than 80 score (PCDL Score) and mass error $< \pm 10$ ppm were only selected for characterization and $\mathrm{m} / \mathrm{z}$ verification purposes.

A total of 98 different phenolic compounds were characterized in both Keitt and K\&P peel samples, including 34 phenolic acids, 53 flavonoids, 3 lignans, and 8 other polyphenols. In general, phenolic compounds had higher diversity in the Keitt peel as compared to K\&P peel sample. Flavonoids (mainly O-glycosylated) and phenolic acids were the major groups in two mango peel samples. Several compounds of lignans and other polyphenols were also reported in both mango peel samples.

In the Keitt peel sample, a total of 71 different phenolic compounds were detected (Table S1Supplementary Materials), including 23 phenolic acids, 43 flavonoids, one lignans, and four other polyphenols, while K\&P peel has a total of 63 different phenolic compounds (Table S2-Supplementary Materials), including 23 phenolic acids, 32 flavonoids, two lignans, and six other polyphenols.

\subsubsection{Phenolic Acid}

For the phenolic acids, five sub-classes were detected in both peel samples: hydroxybenzoic acids, hydroxycinnamic acids, hydroxyphenylacetic acids, hydroxyphenylpentanoic acids, and hydroxyphenylpropanoic acids while hydroxybenzoic acids and hydroxycinnamic acids were the dominant subclasses.

\section{Hydroxybenzoic Acid Derivatives}

Seven out of twelve different hydroxybenzoic acids (Compound 1, 4, 5, 6, 8, 10, 11) were tentatively characterized in both mango peels. Gallic acid and its derivatives were identified in both positive and negative modes in mango peel samples. Compound (1) with $[\mathrm{M}+\mathrm{H}]^{+}$at $\mathrm{m} / \mathrm{z} 171.0290$ and $[\mathrm{M}-\mathrm{H}]^{-}$ at $\mathrm{m} / \mathrm{z} 169.0150$ were tentatively assigned as gallic acid. Gallic acid was previously identified in mango by-products (peel and seed) of three different varieties, including Keitt [8].

Compound (5) with the molecular formula $\mathrm{C}_{14} \mathrm{H}_{16} \mathrm{O}_{10}$ and having the precursor ion at $\mathrm{m} / \mathrm{z} 343.0667$ in the negative $\mathrm{ESI}^{-}$mode, were tentatively characterized as 5-O-galloylquinic acid in both mango peel samples. Compound (4) was tentatively identified in negative $[\mathrm{M}-\mathrm{H}]^{-}$at $\mathrm{m} / \mathrm{z} 137.0253$ and positive mode $[\mathrm{M}+\mathrm{H}]^{+}$at $\mathrm{m} / \mathrm{z} 139.0385$ of ionization, respectively, characterized as 2-hydroxybenzoic acid. Compound (11) was also tentatively identified in both ionization modes, $[\mathrm{M}+\mathrm{H}]^{+}$at $\mathrm{m} / \mathrm{z} 333.0802$ and 
$[\mathrm{M}-\mathrm{H}]^{-}$at $\mathrm{m} / \mathrm{z} 331.0688$, were tentatively characterized as galloyl glucose. 2-hydroxybenzoic acid and galloyl glucose in different mango peels were both already been characterized [18]. Two derivatives of gallic acid were detected in both mango peels, including 3,4-O-dimethylgallic acid (Compound 10) with $[\mathrm{M}+\mathrm{H}]^{+}$at $\mathrm{m} / \mathrm{z}$ 199.0586, and gallic acid 3-O-gallate (Compound 6) with $[\mathrm{M}+\mathrm{H}]^{+}$at $\mathrm{m} / \mathrm{z} 322.0325$ and $\left[\mathrm{M}-\mathrm{H}^{-}\right.$at $\mathrm{m} / \mathrm{z} 321.0260$, respectively. These compounds were also previously characterized in mango by-products, including peels and seeds [8]. Compound (8) with $[\mathrm{M}+\mathrm{H}]^{+}$at $\mathrm{m} / \mathrm{z} 303.0123$ was tentatively identified as ellagic acid. The observation of ellagic acid in K\&P peel was consistent with the work of Pierson, Monteith, Roberts-Thomson, Dietzgen, Gidley, and Shaw [9] and Ajila, et al. [19] have also identified ellagic acid in other mango peels.

Compound (9), with the molecular formula $\mathrm{C}_{20} \mathrm{H}_{16} \mathrm{O}_{13}$ and having the precursor ion $[\mathrm{M}+\mathrm{H}]^{+}$at $\mathrm{m} / \mathrm{z} 465.0645$ in the positive ionization mode, was tentatively characterized as ellagic acid glucoside. Compound (12) with $[\mathrm{M}-\mathrm{H}]^{-}$at $\mathrm{m} / \mathrm{z} 603.0076$ was tentatively identified as gallagic acid. Ellagic acid glucoside and gallagic acid were both only identified in Keitt peel. However, (Compound 2, 3, 7) were only detected in K\&P mango peel samples and tentatively characterized as 2,3-dihydroxybenzoic acid, 4-hydroxybenzoic acid 4-O-glucoside, and 4-O-methylgallic acid, respectively. Dorta, González, Lobo, Sánchez-Moreno, and de Ancos [8] have previously identified 4-O-methylgallic acid in three different mango varieties (Keitt, Sensation, and Gomera 3) and their by-products (peel and seed).

\section{Hydroxycinnamic Acid Derivatives}

Four out of sixteen hydroxycinnamic acid derivatives (Compound 13, 17, 20, 24) were detected in both mango peels, among which three compounds were tentatively identified in negative ESI ${ }^{-}$mode in both peel samples: 3-caffeoylquinic acid (Compound 17) with $[\mathrm{M}-\mathrm{H}]^{-}$at $\mathrm{m} / \mathrm{z} 353.0891$ and $[\mathrm{M}-\mathrm{H}]^{-}$ at $\mathrm{m} / \mathrm{z}$ 353.0903, $p$-coumaric acid 4-O-glucoside (Compound 20) with $[\mathrm{M}-\mathrm{H}]^{-}$at $\mathrm{m} / \mathrm{z} 325.0914$ and $[\mathrm{M}-\mathrm{H}]^{-}$at $\mathrm{m} / \mathrm{z} 325.0934$, and ferulic acid 4-O-glucuronide (Compound 24) with $[\mathrm{M}-\mathrm{H}]^{-}$at $\mathrm{m} / \mathrm{z}$ 369.0853; while, cinnamic acid was tentatively identified in $\mathrm{ESI}^{+}$mode in both peels (Compound 13) with both precursor ions $[\mathrm{M}+\mathrm{H}]^{+}$at $\mathrm{m} / \mathrm{z}$ 149.0592. Abdalla, et al. [20] have previously identified cinnamic acid in four different Egyptian mango seed by-products.

Six hydroxycinnamic acid derivatives (Compound 14, 21, 25, 26, 27, 28) were only detected in the Keitt peel sample. Three compounds were tentatively characterized in $\mathrm{ESI}^{+}$mode, including 1,5-dicaffeoylquinic acid (Compound 14), 3-p-coumaroylquinic acid (Compound 26) and $p$-coumaroyl tartaric acid (Compound 28) with $[\mathrm{M}+\mathrm{H}]^{+}$at $\mathrm{m} / \mathrm{z}$ 517.1343, 339.1086, and 297.0600, respectively. Another three compounds were tentatively characterized in $\mathrm{ESI}^{-}$mode, including chicoric acid (Compound 21), sinapine (Compound 25), and verbascoside (Compound 27), with $[\mathrm{M}-\mathrm{H}]^{-}$at $\mathrm{m} / \mathrm{z}$ 473.0709, 309.1572, and 623.1973, respectively.

However, six hydroxycinnamic acid derivatives (Compound 15, 16, 18, 19, 22, 23) were only detected in the K\&P peel sample and four of the six were tentatively identified in the negative $\mathrm{ESI}^{-}$ mode as isoferulic acid (Compound 18), ferulic acid 4-sulfate (Compound 23), feruloyl tartaric acid (Compound 15), and ferulic acid 4-O-glucoside (Compound 19) with $[\mathrm{M}-\mathrm{H}]^{-}$at $\mathrm{m} / \mathrm{z} 193.0510,273.0086$, 325.0570, and 355.1038, respectively. Compound (22) and (16) showed a precursor ion $[\mathrm{M}+\mathrm{H}]^{+}$at $\mathrm{m} / \mathrm{z} 225.0764$ and 357.0802 respectively were tentatively assigned as sinapic acid and caffeic acid 3-O-glucuronide.

Hydroxycinnamic acids and derivatives were previously identified in different mango varieties [20,21]. In the current study, most of the detected hydroxycinnamic acids are found in the form of quinic acid, tartaric acid, and glycosides derivatives, which is because hydroxycinnamic acids mostly present in nature in conjugated with carbohydrates or cyclic alcohol-acid, such as quinic acid [22]. 
Table 2. Phenolic compounds detected and tentatively characterized in mango peel extracts by using liquid chromatography coupled to electrospray ionisation and quadrupole time of flight mass spectrometry (LC-ESI-QTOF-MS) in positive and negative ionisation modes.

\begin{tabular}{|c|c|c|c|c|c|c|c|c|c|}
\hline No. & Proposed Compounds & $\begin{array}{l}\text { Molecular } \\
\text { Formula }\end{array}$ & $\begin{array}{c}\mathrm{RT} \\
(\mathrm{min})\end{array}$ & Ionization Mode & $\begin{array}{l}\text { Molecular } \\
\text { Weight }\end{array}$ & $\begin{array}{l}\text { Theoretical } \\
(\mathrm{m} / \mathrm{z})\end{array}$ & $\begin{array}{l}\text { Observed } \\
(\mathrm{m} / \mathrm{z})\end{array}$ & $\begin{array}{l}\text { Mass Error } \\
(\mathrm{ppm})\end{array}$ & $\begin{array}{c}\text { Mango Peel } \\
\text { Samples }\end{array}$ \\
\hline \multicolumn{10}{|c|}{ Phenolic acids } \\
\hline \multicolumn{10}{|c|}{ Hydroxybenzoic acids } \\
\hline 1 & Gallic acid & $\mathrm{C}_{7} \mathrm{H}_{6} \mathrm{O}_{5}$ & 6.73 & ${ }^{*}[\mathrm{M}-\mathrm{H}]^{-} /[\mathrm{M}+\mathrm{H}]^{+}$ & 170.0215 & 169.0142 & 169.0150 & 4.73 & Keitt, ${ }^{*} \mathrm{~K} \& \mathrm{P}$ \\
\hline 2 & 2,3-Dihydroxybenzoic acid & $\mathrm{C}_{7} \mathrm{H}_{6} \mathrm{O}_{4}$ & 9.14 & {$[\mathrm{M}-\mathrm{H}]^{-}$} & 154.0266 & 153.0193 & 153.0196 & 1.96 & K\&P \\
\hline 3 & 4-Hydroxybenzoic acid 4-O-glucoside & $\mathrm{C}_{13} \mathrm{H}_{16} \mathrm{O}_{8}$ & 10.92 & {$[\mathrm{M}-\mathrm{H}]^{-}$} & 300.0845 & 299.0772 & 299.0774 & 0.67 & K\&P \\
\hline 4 & 2-Hydroxybenzoic acid & $\mathrm{C}_{7} \mathrm{H}_{6} \mathrm{O}_{3}$ & 10.93 & {$[\mathrm{M}-\mathrm{H}]^{-} / *[\mathrm{M}+\mathrm{H}]^{+}$} & 138.0317 & 139.0390 & 139.0385 & -3.60 & ${ }^{*}$ Keitt, K\&P \\
\hline 5 & 5-O-Galloylquinic acid & $\mathrm{C}_{14} \mathrm{H}_{16} \mathrm{O}_{10}$ & 12.09 & {$[\mathrm{M}-\mathrm{H}]^{-}$} & 344.0743 & 343.0670 & 343.0667 & -0.87 & ${ }^{*}$ Keitt, K\&P \\
\hline 6 & Gallic acid 3-O-gallate & $\mathrm{C}_{14} \mathrm{H}_{10} \mathrm{O}_{9}$ & 16.35 & {$[\mathrm{M}-\mathrm{H}]^{-} / *[\mathrm{M}+\mathrm{H}]^{+}$} & 322.0325 & 323.0398 & 323.0391 & -2.17 & ${ }^{*}$ Keitt, K\&P \\
\hline 7 & 4-O-Methylgallic acid & $\mathrm{C}_{8} \mathrm{H}_{8} \mathrm{O}_{5}$ & 18.76 & {$[\mathrm{M}-\mathrm{H}]^{-}$} & 184.0372 & 183.0299 & 183.0303 & 2.19 & K\&P \\
\hline 8 & Ellagic acid & $\mathrm{C}_{14} \mathrm{H}_{6} \mathrm{O}_{8}$ & 19.51 & {$[\mathrm{M}+\mathrm{H}]^{+}$} & 302.0063 & 303.0136 & 303.0123 & -4.29 & ${ }^{*}$ Keitt, K\&P \\
\hline 9 & Ellagic acid glucoside & $\mathrm{C}_{20} \mathrm{H}_{16} \mathrm{O}_{13}$ & 19.51 & {$[\mathrm{M}+\mathrm{H}]^{+}$} & 464.0591 & 465.0664 & 465.0645 & -4.09 & Keitt \\
\hline 10 & 3,4-O-Dimethylgallic acid & $\mathrm{C}_{9} \mathrm{H}_{10} \mathrm{O}_{5}$ & 31.14 & {$[\mathrm{M}+\mathrm{H}]^{+}$} & 198.0528 & 199.0601 & 199.0586 & -7.54 & ${ }^{*}$ Keitt, K\&P \\
\hline 11 & Galloyl glucose & $\mathrm{C}_{13} \mathrm{H}_{16} \mathrm{O}_{10}$ & 32.02 & {$[\mathrm{M}-\mathrm{H}]^{-} / *[\mathrm{M}+\mathrm{H}]^{+}$} & 332.0743 & 333.0816 & 333.0802 & -4.20 & ${ }^{*}$ Keitt, K\&P \\
\hline \multirow{2}{*}{\multicolumn{10}{|c|}{ Hydroxycinnamic acids }} \\
\hline & & & & & & & & & \\
\hline 13 & Cinnamic acid & $\mathrm{C}_{9} \mathrm{H}_{8} \mathrm{O}_{2}$ & 9.21 & {$[\mathrm{M}+\mathrm{H}]^{+}$} & 148.0524 & 149.0597 & 149.0592 & -3.35 & ${ }^{*}$ Keitt, K\&P \\
\hline 14 & 1,5-Dicaffeoylquinic acid & $\mathrm{C}_{25} \mathrm{H}_{24} \mathrm{O}_{12}$ & 9.77 & {$[\mathrm{M}+\mathrm{H}]^{+}$} & 516.1268 & 517.1341 & 517.1343 & 0.39 & Keitt \\
\hline 15 & Feruloyl tartaric acid & $\mathrm{C}_{14} \mathrm{H}_{14} \mathrm{O}_{9}$ & 10.74 & {$[\mathrm{M}-\mathrm{H}]^{-}$} & 326.0638 & 325.0565 & 325.0570 & 1.54 & K\&P \\
\hline 16 & Caffeic acid 3-O-glucuronide & $\mathrm{C}_{15} \mathrm{H}_{16} \mathrm{O}_{10}$ & 13.12 & {$[\mathrm{M}+\mathrm{H}]^{+}$} & 356.0743 & 357.0816 & 357.0802 & -3.92 & K\&P \\
\hline 17 & 3-Caffeoylquinic acid & $\mathrm{C}_{16} \mathrm{H}_{18} \mathrm{O}_{9}$ & 17.95 & {$[\mathrm{M}-\mathrm{H}]^{-}$} & 354.0951 & 353.0878 & 353.0891 & 3.68 & ${ }^{*}$ Keitt, K\&P \\
\hline 18 & Isoferulic acid & $\mathrm{C}_{10} \mathrm{H}_{10} \mathrm{O}_{4}$ & 18.06 & {$[\mathrm{M}-\mathrm{H}]^{-}$} & 194.0579 & 193.0506 & 193.0510 & 2.07 & K\&P \\
\hline 19 & Ferulic acid 4-O-glucoside & $\mathrm{C}_{16} \mathrm{H}_{20} \mathrm{O}_{9}$ & 18.08 & {$[\mathrm{M}-\mathrm{H}]^{-}$} & 356.1107 & 355.1034 & 355.1038 & 1.13 & K\&P \\
\hline 20 & $p$-Coumaric acid 4-O-glucoside & $\mathrm{C}_{15} \mathrm{H}_{18} \mathrm{O}_{8}$ & 19.10 & {$[\mathrm{M}-\mathrm{H}]^{-}$} & 326.1002 & 325.0929 & 325.0914 & -4.61 & ${ }^{*}$ Keitt, K\&P \\
\hline 21 & Chicoric acid & $\mathrm{C}_{22} \mathrm{H}_{18} \mathrm{O}_{12}$ & 20.21 & {$[\mathrm{M}-\mathrm{H}]^{-}$} & 474.0798 & 473.0725 & 473.0709 & -3.38 & Keitt \\
\hline 22 & Sinapic acid & $\mathrm{C}_{11} \mathrm{H}_{12} \mathrm{O}_{5}$ & 20.68 & {$[\mathrm{M}+\mathrm{H}]^{+}$} & 224.0685 & 225.0758 & 225.0764 & 2.67 & $K \& P$ \\
\hline 23 & Ferulic acid 4-sulfate & $\mathrm{C}_{10} \mathrm{H}_{10} \mathrm{O}_{7} \mathrm{~S}$ & 21.33 & {$[\mathrm{M}-\mathrm{H}]^{-}$} & 274.0147 & 273.0074 & 273.0086 & 4.40 & K\&P \\
\hline 24 & Ferulic acid 4-O-glucuronide & $\mathrm{C}_{16} \mathrm{H}_{18} \mathrm{O}_{10}$ & 21.83 & {$[\mathrm{M}-\mathrm{H}]^{-}$} & 370.0900 & 369.0827 & 369.0853 & 7.04 & ${ }^{*}$ Keitt, K\&P \\
\hline 25 & Sinapine & $\mathrm{C}_{16} \mathrm{H}_{24} \mathrm{NO}_{5}$ & 24.56 & {$[\mathrm{M}-\mathrm{H}]^{-}$} & 310.1654 & 309.1581 & 309.1572 & -2.91 & Keitt \\
\hline 26 & 3-p-Coumaroylquinic acid & $\mathrm{C}_{16} \mathrm{H}_{18} \mathrm{O}_{8}$ & 27.28 & {$[\mathrm{M}+\mathrm{H}]^{+}$} & 338.1002 & 339.1075 & 339.1086 & 3.24 & Keitt \\
\hline 27 & Verbascoside & $\mathrm{C}_{29} \mathrm{H}_{36} \mathrm{O}_{15}$ & 31.31 & {$[\mathrm{M}-\mathrm{H}]^{-}$} & 624.2054 & 623.1981 & 623.1973 & -1.28 & Keitt \\
\hline 28 & & \multicolumn{2}{|c|}{ Hydroxyphenylacetic acids } & {$[\mathrm{M}+\mathrm{H}]^{+}$} & 296.0532 & 297.0605 & 297.0600 & -1.68 & Keitt \\
\hline 29 & $\begin{array}{l}\text { 3,4-Dihydroxyphenylacetic acid } \\
\text { Hydroxyphenylpentanoic acids }\end{array}$ & $\mathrm{C}_{8} \mathrm{H}_{8} \mathrm{O}_{4}$ & 20.16 & {$[\mathrm{M}-\mathrm{H}]^{-} / *[\mathrm{M}+\mathrm{H}]^{+}$} & 168.0423 & 169.0496 & 169.0493 & -1.77 & ${ }^{*}$ Keitt, K\&P \\
\hline 30 & 5-(3',5'-dihydroxyphenyl)- $\gamma$-valerolactone 3-O-glucuronide & $\mathrm{C}_{17} \mathrm{H}_{20} \mathrm{O}_{10}$ & 13.58 & {$[\mathrm{M}-\mathrm{H}]^{-}$} & 384.1056 & 383.0983 & 383.0995 & 3.13 & Keitt \\
\hline 31 & 5-(3'-Methoxy-4'-hydroxyphenyl)- $\gamma$-valerolactone & $\mathrm{C}_{12} \mathrm{H}_{14} \mathrm{O}_{4}$ & 19.10 & {$[\mathrm{M}-\mathrm{H}]^{-}$} & 222.0892 & 221.0819 & 221.0827 & 3.62 & Keitt \\
\hline 32 & 5-( $3^{\prime}, 4^{\prime}$-dihydroxyphenyl)-valeric acid & $\mathrm{C}_{11} \mathrm{H}_{14} \mathrm{O}_{4}$ & 24.61 & {$[\mathrm{M}-\mathrm{H}]^{-}$} & 210.0892 & 209.0819 & 209.0821 & 0.96 & $K \& P$ \\
\hline
\end{tabular}


Table 2. Cont

\begin{tabular}{|c|c|c|c|c|c|c|c|c|c|}
\hline No. & Proposed Compounds & $\begin{array}{l}\text { Molecular } \\
\text { Formula }\end{array}$ & $\begin{array}{c}\mathrm{RT} \\
(\mathrm{min})\end{array}$ & Ionization Mode & $\begin{array}{l}\text { Molecular } \\
\text { Weight }\end{array}$ & $\begin{array}{l}\text { Theoretical } \\
(\mathrm{m} / \mathrm{z})\end{array}$ & $\begin{array}{l}\text { Observed } \\
(\mathrm{m} / \mathrm{z})\end{array}$ & $\begin{array}{l}\text { Mass Error } \\
(\mathrm{ppm})\end{array}$ & $\begin{array}{c}\text { Mango Peel } \\
\text { Samples }\end{array}$ \\
\hline & Hydroxyphenylpropanoic acids & & & & & & & & \\
\hline 33 & Dihydroferulic acid 4-O-glucuronide & $\mathrm{C}_{16} \mathrm{H}_{20} \mathrm{O}_{10}$ & 10.86 & {$[\mathrm{M}-\mathrm{H}]^{-}$} & 372.1056 & 371.0983 & 371.1008 & 6.74 & K\&P \\
\hline 34 & 3-Hydroxy-3-(3-hydroxyphenyl) propionic acid & $\mathrm{C}_{9} \mathrm{H}_{10} \mathrm{O}_{4}$ & 82.03 & {$[\mathrm{M}+\mathrm{H}]^{+}$} & 182.0579 & 183.0652 & 183.0663 & 6.01 & Keitt \\
\hline \multicolumn{10}{|c|}{ Flavonoids } \\
\hline & Anthocyanins & & & & & & & & \\
\hline 35 & Cyanidin 3-O-(6"-p-coumaroyl-glucoside) & $\mathrm{C}_{30} \mathrm{H}_{27} \mathrm{O}_{13}$ & 14.55 & {$[\mathrm{M}+\mathrm{H}]^{+}$} & 595.1452 & 596.1525 & 596.1508 & -2.85 & $\mathrm{~K} \& \mathrm{P}$ \\
\hline 36 & Vitisin A & $\mathrm{C}_{26} \mathrm{H}_{25} \mathrm{O}_{14}$ & 24.32 & {$[\mathrm{M}-\mathrm{H}]^{-}$} & 561.1244 & 560.1171 & 560.1155 & -2.86 & Keitt \\
\hline 37 & 4-O-Methyldelphinidin 3-O-D-glucoside & $\mathrm{C}_{22} \mathrm{H}_{23} \mathrm{O}_{12}$ & 29.14 & {$[\mathrm{M}-\mathrm{H}]^{-}$} & 479.1190 & 478.1117 & 478.1094 & -4.81 & Keitt \\
\hline 38 & Delphinidin 3-O-sambubioside & $\mathrm{C}_{26} \mathrm{H}_{29} \mathrm{O}_{16}$ & 34.04 & {$[\mathrm{M}-\mathrm{H}]^{-}$} & 597.1456 & 596.1383 & 596.1367 & -2.68 & ${ }^{*}$ Keitt, K\&P \\
\hline 39 & Isopeonidin 3-O-arabinoside & $\mathrm{C}_{21} \mathrm{H}_{21} \mathrm{O}_{10}$ & 37.36 & {$[\mathrm{M}-\mathrm{H}]^{-}$} & 433.1135 & 432.1062 & 432.1059 & -0.69 & K\&P \\
\hline 40 & Delphinidin 3-O-glucoside & $\mathrm{C}_{21} \mathrm{H}_{21} \mathrm{O}_{12}$ & 38.68 & {$[\mathrm{M}-\mathrm{H}]^{-}$} & 465.1033 & 464.0960 & 464.0947 & -2.80 & ${ }^{*}$ Keitt, K\&P \\
\hline 41 & Cyanidin 3-O-galactoside & $\mathrm{C}_{21} \mathrm{H}_{21} \mathrm{O}_{11}$ & 43.35 & {$[\mathrm{M}-\mathrm{H}]^{-}$} & 449.1084 & 448.1011 & 448.1002 & -2.01 & ${ }^{*}$ Keitt, K\&P \\
\hline 42 & Delphinidin 3-O-arabinoside & $\mathrm{C}_{20} \mathrm{H}_{19} \mathrm{O}_{11}$ & 43.43 & {$[\mathrm{M}-\mathrm{H}]^{-}$} & 435.0927 & 434.0854 & 434.0843 & -2.53 & ${ }^{*}$ Keitt, K\&P \\
\hline 43 & 4'-O-Methylcyanidin 3-O-D-glucoside & $\mathrm{C}_{22} \mathrm{H}_{23} \mathrm{O}_{11}$ & 74.49 & {$[\mathrm{M}-\mathrm{H}]^{-}$} & 463.1240 & 462.1167 & 462.1167 & 0. & Keitt \\
\hline 44 & $\begin{array}{l}\text { Pelargonidin 3,5-O-diglucoside } \\
\text { Dihydrochalcones }\end{array}$ & $\mathrm{C}_{27} \mathrm{H}_{31} \mathrm{ClO}_{15}$ & 77.26 & {$[\mathrm{M}+\mathrm{H}]^{+}$} & 630.1351 & 631.1424 & 631.1408 & -2.54 & $\mathrm{~K} \& \mathrm{P}$ \\
\hline 45 & 3-Hydroxyphloretin 2'-O-glucoside & $\mathrm{C}_{21} \mathrm{H}_{24} \mathrm{O}_{11}$ & 28.80 & {$[\mathrm{M}-\mathrm{H}]^{-}$} & 452.1319 & 451.1246 & 451.1239 & -1.55 & ${ }^{*}$ Keitt, K\&P \\
\hline 46 & 3-Hydroxyphloretin 2'-O-xylosyl-glucoside & $\mathrm{C}_{26} \mathrm{H}_{32} \mathrm{O}_{15}$ & 38.83 & {$[\mathrm{M}-\mathrm{H}]^{-}$} & 584.1741 & 583.1668 & 583.1665 & -0.51 & Keitt \\
\hline 47 & $\begin{array}{l}\text { Phloretin 2'-O-xylosyl-glucoside } \\
\text { Chalcones }\end{array}$ & $\mathrm{C}_{26} \mathrm{H}_{32} \mathrm{O}_{14}$ & 44.99 & {$[\mathrm{M}-\mathrm{H}]^{-}$} & 568.1792 & 567.1719 & 567.1705 & -2.47 & Keitt \\
\hline 48 & $\begin{array}{l}\text { Xanthohumol } \\
\text { Dihydroflavonols }\end{array}$ & $\mathrm{C}_{21} \mathrm{H}_{22} \mathrm{O}_{5}$ & 77.48 & {$[\mathrm{M}+\mathrm{H}]^{+}$} & 354.1467 & 355.1540 & 355.1542 & 0.56 & K\&P \\
\hline 49 & Dihydromyricetin 3-O-rhamnoside & $\mathrm{C}_{21} \mathrm{H}_{22} \mathrm{O}_{12}$ & 24.56 & {$[\mathrm{M}-\mathrm{H}]^{-}$} & 466.1111 & 465.1038 & 465.1061 & 4.95 & Keitt \\
\hline 50 & Dihydroquercetin 3-O-rhamnoside & $\mathrm{C}_{21} \mathrm{H}_{22} \mathrm{O}_{11}$ & 30.33 & {$[\mathrm{M}-\mathrm{H}]^{-}$} & 450.1162 & 449.1089 & 449.1112 & 5.12 & Keitt \\
\hline 51 & $\begin{array}{l}\text { Dihydroquercetin } \\
\text { Flavanols }\end{array}$ & $\mathrm{C}_{15} \mathrm{H}_{12} \mathrm{O}_{7}$ & 38.88 & {$[\mathrm{M}-\mathrm{H}]^{-}$} & 304.0583 & 303.0510 & 303.0521 & 3.63 & Keitt \\
\hline 52 & 4'-O-Methylepigallocatechin & $\mathrm{C}_{16} \mathrm{H}_{16} \mathrm{O}_{7}$ & 7.63 & {$[\mathrm{M}+\mathrm{H}]^{+}$} & 320.0896 & 321.0969 & 321.0964 & -1.56 & Keitt \\
\hline 53 & Procyanidin dimer B1 & $\mathrm{C}_{30} \mathrm{H}_{26} \mathrm{O}_{12}$ & 14.91 & {$[\mathrm{M}-\mathrm{H}]^{-}$} & 578.1424 & 577.1351 & 577.1363 & 2.08 & ${ }^{*}$ Keitt, K\&P \\
\hline 54 & 4'-O-Methyl-(-)-epigallocatechin 7-O-glucuronide & $\mathrm{C}_{22} \mathrm{H}_{24} \mathrm{O}_{13}$ & 17.04 & {$[\mathrm{M}+\mathrm{H}]^{+}$} & 496.1217 & 497.1290 & 497.1312 & 4.43 & Keitt \\
\hline 55 & Procyanidin trimer $\mathrm{C} 1$ & $\mathrm{C}_{45} \mathrm{H}_{38} \mathrm{O}_{18}$ & 18.53 & {$[\mathrm{M}-\mathrm{H}]^{-}$} & 866.2058 & 865.1985 & 865.2003 & 2.08 & Keitt \\
\hline 56 & (-)-Epicatechin & $\mathrm{C}_{15} \mathrm{H}_{14} \mathrm{O}_{6}$ & 19.06 & {$[\mathrm{M}-\mathrm{H}]^{-}$} & 290.0790 & 289.0717 & 289.0740 & 7.96 & ${ }^{*}$ Keitt, K\&P \\
\hline 57 & 3'-O-Methyl-(-)-epicatechin 7-O-glucuronide & $\mathrm{C}_{22} \mathrm{H}_{24} \mathrm{O}_{12}$ & 30.34 & {$[\mathrm{M}-\mathrm{H}]^{-}$} & 480.1268 & 479.1195 & 479.1225 & 6.26 & Keitt \\
\hline 58 & (-)-Epigallocatechin 3'-O-glucuronide & $\mathrm{C}_{21} \mathrm{H}_{22} \mathrm{O}_{13}$ & 31.01 & {$[\mathrm{M}+\mathrm{H}]^{+}$} & 482.1060 & 483.1133 & 483.1100 & -6.83 & Keitt \\
\hline 59 & $\begin{array}{l}(+) \text {-Catechin 3-O-gallate } \\
\text { Flavanones }\end{array}$ & $\mathrm{C}_{22} \mathrm{H}_{18} \mathrm{O}_{10}$ & 37.15 & {$[\mathrm{M}-\mathrm{H}]^{-}$} & 442.0900 & 441.0827 & 441.0850 & 5.21 & ${ }^{*}$ Keitt, K\&P \\
\hline 60 & Hesperidin & $\mathrm{C}_{28} \mathrm{H}_{34} \mathrm{O}_{15}$ & 40.85 & {$[\mathrm{M}-\mathrm{H}]^{-}$} & 610.1898 & 609.1825 & 609.1818 & -1.15 & Keitt \\
\hline 61 & Hesperetin $3^{\prime}$-O-glucuronide & $\mathrm{C}_{22} \mathrm{H}_{22} \mathrm{O}_{12}$ & 63.19 & {$[\mathrm{M}+\mathrm{H}]^{+}$} & 478.1111 & 479.1184 & 479.1162 & -4.59 & ${ }^{*}$ Keitt, K\&P \\
\hline
\end{tabular}


Table 2. Cont

\begin{tabular}{|c|c|c|c|c|c|c|c|c|c|}
\hline No. & Proposed Compounds & $\begin{array}{l}\text { Molecular } \\
\text { Formula }\end{array}$ & $\begin{array}{c}\mathrm{RT} \\
\text { (min) }\end{array}$ & Ionization Mode & $\begin{array}{l}\text { Molecular } \\
\text { Weight }\end{array}$ & $\begin{array}{l}\text { Theoretical } \\
(\mathrm{m} / \mathrm{z})\end{array}$ & $\begin{array}{l}\text { Observed } \\
(\mathrm{m} / \mathrm{z})\end{array}$ & $\begin{array}{l}\text { Mass Error } \\
(\mathrm{ppm})\end{array}$ & $\begin{array}{l}\text { Mango Peel } \\
\text { Samples }\end{array}$ \\
\hline \multicolumn{10}{|c|}{ Flavones } \\
\hline 62 & Apigenin 7-O-glucuronide & $\mathrm{C}_{21} \mathrm{H}_{18} \mathrm{O}_{11}$ & 11.34 & {$[\mathrm{M}+\mathrm{H}]^{+}$} & 446.0849 & 447.0922 & 447.0938 & 3.58 & Keitt \\
\hline 63 & Chrysoeriol 7-O-glucoside & $\mathrm{C}_{22} \mathrm{H}_{22} \mathrm{O}_{11}$ & 27.53 & {$[\mathrm{M}+\mathrm{H}]^{+}$} & 462.1162 & 463.1235 & 463.1204 & -6.69 & ${ }^{*}$ Keitt, K\&P \\
\hline 64 & Apigenin 7-O-apiosyl-glucoside & $\mathrm{C}_{26} \mathrm{H}_{28} \mathrm{O}_{14}$ & 31.26 & {$[\mathrm{M}+\mathrm{H}]^{+}$} & 564.1479 & 565.1552 & 565.1538 & -2.48 & K\&P \\
\hline 65 & Apigenin 6-C-glucoside & $\mathrm{C}_{21} \mathrm{H}_{20} \mathrm{O}_{10}$ & 37.37 & {$[\mathrm{M}+\mathrm{H}]^{+}$} & 432.1056 & 433.1129 & 433.1108 & -4.85 & ${ }^{*}$ Keitt, K\&P \\
\hline 66 & Apigenin 6,8-di-C-glucoside & $\mathrm{C}_{27} \mathrm{H}_{30} \mathrm{O}_{15}$ & 42.90 & {$[\mathrm{M}-\mathrm{H}]^{-}$} & 594.1585 & 593.1512 & 593.1506 & -1.01 & Keitt \\
\hline \multicolumn{10}{|c|}{ Flavonols } \\
\hline 68 & 3-Methoxysinensetin & $\mathrm{C}_{21} \mathrm{H}_{22} \mathrm{O}_{8}$ & 8.41 & {$[\mathrm{M}-\mathrm{H}]^{-}$} & 402.1315 & 401.1242 & 401.1245 & 0.75 & Keitt \\
\hline 69 & Quercetin 3'-O-glucuronide & $\mathrm{C}_{21} \mathrm{H}_{18} \mathrm{O}_{13}$ & 17.03 & {$[\mathrm{M}+\mathrm{H}]^{+}$} & 478.0747 & 479.0820 & 479.0802 & -3.76 & Keitt \\
\hline 70 & Myricetin 3-O-rutinoside & $\mathrm{C}_{27} \mathrm{H}_{30} \mathrm{O}_{17}$ & 21.22 & {$[\mathrm{M}-\mathrm{H}]^{-}$} & 626.1483 & 625.1410 & 625.1433 & 3.68 & ${ }^{*}$ Keitt, K\&P \\
\hline 71 & Quercetin 3-O-glucosyl-xyloside & $\mathrm{C}_{26} \mathrm{H}_{28} \mathrm{O}_{16}$ & 25.81 & {$[\mathrm{M}-\mathrm{H}]^{-}$} & 596.1377 & 595.1304 & 595.1334 & 5.04 & ${ }^{*}$ Keitt, K\&P \\
\hline 72 & Kaempferol 3-O-glucosyl-rhamnosyl-galactoside & $\mathrm{C}_{33} \mathrm{H}_{40} \mathrm{O}_{20}$ & 37.10 & {$[\mathrm{M}-\mathrm{H}]^{-} / *[\mathrm{M}+\mathrm{H}]^{+}$} & 756.2113 & 757.2186 & 757.2154 & -4.23 & ${ }^{*}$ Keitt, K\&P \\
\hline 73 & Kaempferol 3,7-O-diglucoside & $\mathrm{C}_{27} \mathrm{H}_{30} \mathrm{O}_{16}$ & 37.12 & {$[\mathrm{M}-\mathrm{H}]^{-}$} & 610.1534 & 609.1461 & 609.1451 & -1.64 & ${ }^{*}$ Keitt, K\&P \\
\hline 74 & Myricetin 3-O-rhamnoside & $\mathrm{C}_{21} \mathrm{H}_{20} \mathrm{O}_{12}$ & 38.69 & {$[\mathrm{M}+\mathrm{H}]^{+}$} & 464.0955 & 465.1028 & 465.1000 & -6.02 & ${ }^{*}$ Keitt, K\&P \\
\hline 75 & $\begin{array}{c}\text { Kaempferol 3-O-(2"-rhamnosyl-galactoside }) \\
\text { 7-O-rhamnoside }\end{array}$ & $\mathrm{C}_{33} \mathrm{H}_{40} \mathrm{O}_{19}$ & 39.35 & {$[\mathrm{M}+\mathrm{H}]^{+}$} & 740.2164 & 741.2237 & 741.2227 & -1.35 & K\&P \\
\hline 76 & Quercetin 3-O-arabinoside & $\mathrm{C}_{20} \mathrm{H}_{18} \mathrm{O}_{11}$ & 42.01 & ${ }^{*}[\mathrm{M}-\mathrm{H}]^{-} /[\mathrm{M}+\mathrm{H}]^{+}$ & 434.0849 & 433.0776 & 433.0806 & 6.93 & ${ }^{*}$ Keitt, K\&P \\
\hline 77 & Myricetin & $\mathrm{C}_{15} \mathrm{H}_{10} \mathrm{O}_{8}$ & 56.02 & {$[\mathrm{M}-\mathrm{H}]^{-}$} & 318.0376 & 317.0303 & 317.0309 & 1.89 & $\mathrm{~K} \& \mathrm{P}$ \\
\hline 78 & Isorhamnetin & $\mathrm{C}_{16} \mathrm{H}_{12} \mathrm{O}_{7}$ & 63.19 & {$[\mathrm{M}+\mathrm{H}]^{+}$} & 316.0583 & 317.0656 & 317.0641 & -4.73 & ${ }^{*}$ Keitt, $K \& P$ \\
\hline 79 & Isorhamnetin 3-O-glucoside 7-O-rhamnoside & $\mathrm{C}_{28} \mathrm{H}_{32} \mathrm{O}_{16}$ & 63.25 & {$[\mathrm{M}+\mathrm{H}]^{+}$} & 624.1690 & 625.1763 & 625.1734 & -4.64 & $K \& P$ \\
\hline \multicolumn{9}{|c|}{ Isoflavonoids } & Keitt \\
\hline 81 & $2^{\prime}, 7$-Dihydroxy-4', $5^{\prime}$-dimethoxyisoflavone & $\mathrm{C}_{17} \mathrm{H}_{14} \mathrm{O}_{6}$ & 14.01 & {$[\mathrm{M}+\mathrm{H}]^{+}$} & 314.0790 & 315.0863 & 315.0862 & -0.32 & Keitt \\
\hline 82 & 6"-O-Malonylgenistin & $\mathrm{C}_{24} \mathrm{H}_{22} \mathrm{O}_{13}$ & 17.04 & {$[\mathrm{M}+\mathrm{H}]^{+}$} & 518.1060 & 519.1133 & 519.1137 & 0.77 & Keitt \\
\hline 83 & $3^{\prime}, 4^{\prime}, 5,7-$ Tetrahydroxyisoflavanone & $\mathrm{C}_{15} \mathrm{H}_{12} \mathrm{O}_{6}$ & 17.72 & {$[\mathrm{M}-\mathrm{H}]^{-}$} & 288.0634 & 287.0561 & 287.0570 & 3.14 & ${ }^{*}$ Keitt, K\&P \\
\hline 84 & 3'-Hydroxydaidzein & $\mathrm{C}_{15} \mathrm{H}_{10} \mathrm{O}_{5}$ & 24.25 & {$[\mathrm{M}+\mathrm{H}]^{+}$} & 270.0528 & 271.0601 & 271.0612 & 4.06 & $\mathrm{~K} \& \mathrm{P}$ \\
\hline 85 & $5,6,7,3^{\prime}, 4^{\prime}$-Pentahydroxyisoflavone & $\mathrm{C}_{15} \mathrm{H}_{10} \mathrm{O}_{7}$ & 38.68 & {$[\mathrm{M}-\mathrm{H}]^{-} / *[\mathrm{M}+\mathrm{H}]^{+}$} & 302.0427 & 303.0500 & 303.0482 & -5.94 & ${ }^{*}$ Keitt, K\&P \\
\hline 86 & 3'-Hydroxygenistein & $\mathrm{C}_{15} \mathrm{H}_{10} \mathrm{O}_{6}$ & 43.38 & {$[\mathrm{M}+\mathrm{H}]^{+}$} & 286.0477 & 287.0550 & 287.0540 & -3.48 & ${ }^{*}$ Keitt, K\&P \\
\hline 87 & Equol 7-O-glucuronide & $\mathrm{C}_{21} \mathrm{H}_{22} \mathrm{O}_{9}$ & 59.79 & {$[\mathrm{M}+\mathrm{H}]^{+}$} & 418.1264 & 419.1337 & 419.1328 & -2.15 & $K \& P$ \\
\hline \multicolumn{10}{|c|}{ Lignans } \\
\hline 88 & Schisantherin A & $\mathrm{C}_{30} \mathrm{H}_{32} \mathrm{O}_{9}$ & 32.38 & {$[\mathrm{M}-\mathrm{H}]^{-}$} & 536.2046 & 535.1973 & 535.1958 & -2.80 & Keitt \\
\hline 89 & 1-Acetoxypinoresinol & $\mathrm{C}_{22} \mathrm{H}_{24} \mathrm{O}_{8}$ & 40.01 & {$[\mathrm{M}+\mathrm{H}]^{+}$} & 416.1471 & 417.1544 & 417.1530 & -3.36 & $K \& P$ \\
\hline 90 & Schisandrol B & $\mathrm{C}_{23} \mathrm{H}_{28} \mathrm{O}_{7}$ & 78.67 & {$[\mathrm{M}+\mathrm{H}]^{+}$} & 416.1835 & 417.1908 & 417.1906 & -0.48 & $K \& P$ \\
\hline
\end{tabular}


Table 2. Cont

\begin{tabular}{|c|c|c|c|c|c|c|c|c|c|}
\hline No. & Proposed Compounds & $\begin{array}{l}\text { Molecular } \\
\text { Formula }\end{array}$ & $\begin{array}{l}\text { RT } \\
(\min )\end{array}$ & Ionization Mode & $\begin{array}{l}\text { Molecular } \\
\text { Weight }\end{array}$ & $\begin{array}{l}\text { Theoretical } \\
(\mathrm{m} / \mathrm{z})\end{array}$ & $\begin{array}{l}\text { Observed } \\
(\mathrm{m} / \mathrm{z})\end{array}$ & $\begin{array}{l}\text { Mass Error } \\
\quad(\mathrm{ppm})\end{array}$ & $\begin{array}{l}\text { Mango Peel } \\
\text { Samples }\end{array}$ \\
\hline \multicolumn{10}{|c|}{ Other polyphenols } \\
\hline & Hydroxycoumarins & & & & & & & & \\
\hline 91 & Esculetin & $\mathrm{C}_{9} \mathrm{H}_{6} \mathrm{O}_{4}$ & 23.02 & {$[\mathrm{M}-\mathrm{H}]^{-}$} & 178.0266 & 177.0193 & 177.0202 & 5.08 & $\mathrm{~K} \& \mathrm{P}$ \\
\hline 92 & $\begin{array}{l}\text { 4-Hydroxycoumarin } \\
\text { Hydroxyphenylpropenes }\end{array}$ & $\mathrm{C}_{9} \mathrm{H}_{6} \mathrm{O}_{3}$ & 77.53 & {$[\mathrm{M}+\mathrm{H}]^{+}$} & 162.0317 & 163.0390 & 163.0387 & -1.84 & $\mathrm{~K} \& \mathrm{P}$ \\
\hline 93 & $\begin{array}{l}\text { Anethole } \\
\text { Tyrosols }\end{array}$ & $\mathrm{C}_{10} \mathrm{H}_{12} \mathrm{O}$ & 22.77 & {$[\mathrm{M}+\mathrm{H}]^{+}$} & 148.0888 & 149.0961 & 149.0952 & -6.04 & Keitt \\
\hline 94 & Hydroxytyrosol & $\mathrm{C}_{8} \mathrm{H}_{10} \mathrm{O}_{3}$ & 8.16 & {$[\mathrm{M}-\mathrm{H}]^{-}$} & 154.0630 & 153.0557 & 153.0572 & 9.80 & Keitt \\
\hline 95 & Hydroxytyrosol 4-O-glucoside & $\mathrm{C}_{14} \mathrm{H}_{20} \mathrm{O}_{8}$ & 9.58 & {$[\mathrm{M}-\mathrm{H}]^{-}$} & 316.1158 & 315.1085 & 315.1069 & -5.08 & $K \& P$ \\
\hline 96 & $\begin{array}{l}\text { Demethyloleuropein } \\
\text { Other polyphenols }\end{array}$ & $\mathrm{C}_{24} \mathrm{H}_{30} \mathrm{O}_{13}$ & 19.39 & {$[\mathrm{M}-\mathrm{H}]^{-}$} & 526.1686 & 525.1613 & 525.1630 & 3.24 & $\mathrm{~K} \& \mathrm{P}$ \\
\hline 97 & 3,4-Dihydroxyphenylglycol & $\mathrm{C}_{8} \mathrm{H}_{10} \mathrm{O}_{4}$ & 9.16 & {$[\mathrm{M}+\mathrm{H}]^{+}$} & 170.0579 & 171.0652 & 171.0641 & -6.43 & ${ }^{*}$ Keitt, K\&P \\
\hline 98 & Pyrogallol & $\mathrm{C}_{6} \mathrm{H}_{6} \mathrm{O}_{3}$ & 31.16 & {$[\mathrm{M}-\mathrm{H}]^{-} / *[\mathrm{M}+\mathrm{H}]^{+}$} & 126.0317 & 127.0390 & 127.0382 & -6.30 & ${ }^{*}$ Keitt, K\&P \\
\hline
\end{tabular}

* Example sample used for the LC-ESI-QTOF/MS parameters gathering for each phenolic compound in the selected mode. 


\subsubsection{Flavonoids and Their Derivatives}

Flavonoid conjugates were the major class of the polyphenols detected in both mango peels, including nine subtypes: anthocyanins, chalcones, dihydrochalcones, flavanols, flavanones, flavones, flavonols, dihydroflavonols, and isoflavonoids. Flavonols, anthocyanins and flavanols were the main subtypes in mango peels. Most of the flavonoid conjugates were in the form of glycosides.

\section{Anthocyanins Derivatives}

Four out of ten glycosides of anthocyanins (Compound 38, 40, 41, 42) were tentatively identified in both mango peels, including three delphinidin 3-O-glycosides and one cyanidin 3-O-glycoside. Three delphinidin 3-O-glycosides were tentatively assigned as delphinidin 3-O-arabinoside (Compound 42) with $[\mathrm{M}-\mathrm{H}]^{-}$at $\mathrm{m} / \mathrm{z} 434.0843$, delphinidin 3-O-glucoside (Compound 40) with $[\mathrm{M}-\mathrm{H}]^{-}$at $\mathrm{m} / \mathrm{z} 464.0947$, and delphinidin 3-O-sambubioside (Compound 38) with $[\mathrm{M}-\mathrm{H}]^{-}$at $\mathrm{m} / \mathrm{z} 596.1367$. The cyanidin glycoside was detected with the molecular formula $\mathrm{C}_{21} \mathrm{H}_{21} \mathrm{O}_{11}$ and the precursor ion $[\mathrm{M}-\mathrm{H}]^{-}$at $\mathrm{m} / \mathrm{z} 448.1002$ (Compound 41 ), tentatively characterized as cyanidin 3-O-galactoside. Berardini, et al. [23] also identified cyanidin 3-O-galactoside in "Tommy Atkins" mango peel.

Three anthocyanins derivatives (Compound 36, 37, 43) were tentatively identified only in Keitt peel in the negative ESI- mode, including 4'-O-methylcyanidin 3-O-D-glucoside (Compound 43, $[\mathrm{M}-\mathrm{H}]^{-}$at $\mathrm{m} / \mathrm{z}$ 462.1167), 4-O-methyldelphinidin 3-O-D-glucoside (Compound 37, $[\mathrm{M}-\mathrm{H}]^{-}$at $\mathrm{m} / \mathrm{z}$ 478.1094), and vitisin A (Compound 36, $[\mathrm{M}-\mathrm{H}]^{-}$at $\left.\mathrm{m} / \mathrm{z} 560.1155\right)$, respectively. However, three anthocyanins derivatives (Compound $35,39,44$ ) were tentatively identified only in K\&P peel in both positive and negative ionization modes including isopeonidin 3-O-arabinoside (Compound 39, $[\mathrm{M}-\mathrm{H}]^{-}$at $\mathrm{m} / \mathrm{z}$ 432.1059), pelargonidin 3,5-O-diglucoside (Compound $44,[\mathrm{M}+\mathrm{H}]^{+}$at $\mathrm{m} / \mathrm{z} 631.1408$ ), and cyanidin 3-O-(6"-p-coumaroyl-glucoside) (Compound 35, $[\mathrm{M}+\mathrm{H}]^{+}$at $\mathrm{m} / \mathrm{z}$ 596.1508). respectively. Berardini, Fezer, Conrad, Beifuss, Carle, and Schieber [23] also characterized methylcyanidin glycosides derivatives, 7-O-methylcyanidin 3-O- $\beta$-D-galactopyranoside, from the peel of Tommy Atkins mango. Anthocyanin derivatives were previously identified and found that mango peels contain less anthocyanin as compared with other fruit by-products, such as grape pomace [23,24].

\section{Flavones Derivatives}

Flavones that were detected in mango peel by-products were mainly glycosides and C-glycosides of apigenins. Four out of six flavones derivatives were tentatively identified as apigenin glycosides, which were detected in both mango peels (Compound 65), apigenin 6-C-glucoside, $[\mathrm{M}+\mathrm{H}]^{+}$at m/z 433.1108), two only in Keitt peel (Compound 62), apigenin 7-O-glucuronide, $[\mathrm{M}+\mathrm{H}]^{+}$at $\mathrm{m} / \mathrm{z} 447.0938$; Compound 66, apigenin 6,8-di-C-glucoside, $[\mathrm{M}+\mathrm{H}]^{-}$at $\mathrm{m} / \mathrm{z} 593.1506$, and one only in K\&P peel (Compound 64), apigenin 7-O-apiosyl-glucoside, $[\mathrm{M}+\mathrm{H}]^{+}$at $\mathrm{m} / \mathrm{z} 565.1538$.

Apart from apigenin 6-C-glucoside, another two flavones, chrysoeriol 7-O-glucoside (Compound 63) and 6-hydroxyluteolin 7-O-rhamnoside (Compound 67), were also detected in two mango peels in both positive and negative ionization modes. Lasano, et al. [25] previously identified apigenin in Mangifera odorata fruit, a hybrid mango specie [26]. The detected flavones derivatives were in agreement with Masibo and He [27] and accumulate in fruit as glycosides with sugar.

\section{Flavonols Derivatives}

In the present work, seven out of thirteen flavonols derivatives (Compound 70, 71, 72, 73, 74, 76, 78) were tentatively characterized in both mango peels, including two kaempferol glycosides, two quercetin 3-O-glycosides, two myricetin 3-O-glycosides, and isorhamnetin (Compound 78, $[\mathrm{M}+\mathrm{H}]^{+}$ at $\mathrm{m} / \mathrm{z}$ 317.0656). Two kaempferol-O-glycosides tentatively identified in both mango peels include kaempferol 3,7-O-diglucoside (Compound 73) with $[\mathrm{M}-\mathrm{H}]^{-}$at $\mathrm{m} / \mathrm{z}$ 609.1451, and kaempferol 3-O-glucosyl-rhamnosyl-galactoside (Compound 72), with $[\mathrm{M}+\mathrm{H}]^{+}$at $\mathrm{m} / \mathrm{z} 757.2154$ and $[\mathrm{M}-\mathrm{H}]^{-}$at $\mathrm{m} / \mathrm{z} 755.2030$, respectively. 
Two quercetin 3-O-glycosides that were tentatively identified in both mango peels include quercetin 3-O-arabinoside (Compound 76) with $[\mathrm{M}-\mathrm{H}]^{-}$at $\mathrm{m} / \mathrm{z} 433.0806$ and $[\mathrm{M}+\mathrm{H}]^{+}$at $\mathrm{m} / \mathrm{z} 435.0904$, and quercetin 3-O-glucosyl-xyloside (Compound 71) with $[\mathrm{M}-\mathrm{H}]^{-}$at $\mathrm{m} / \mathrm{z} 595.1334$. Quercetin 3-O-arabinoside was previously identified in mango puree by Schieber, et al. [28]. They also reported six different derivates of quercetin and five different derivates of kaempferol glycosides while using HPLC-MS analysis.

Two myricetin 3-O-glycosides tentatively characterized in both mango peels include myricetin 3-O-rhamnoside (Compound 74) with $[\mathrm{M}+\mathrm{H}]^{+}$at $\mathrm{m} / \mathrm{z} 465.1000$, and myricetin 3-O-rutinoside (Compound 70) with $[\mathrm{M}-\mathrm{H}]^{-}$at $\mathrm{m} / \mathrm{z} 625.1433$.

Three flavonol derivatives (Compound $68,69,80$ ) were tentatively characterized only in Keitt peel in both positive and negative ionization modes, including 3-methoxysinensetin (Compound 68) with $[\mathrm{M}-\mathrm{H}]^{-}$at $\mathrm{m} / \mathrm{z} 401.1245$ and two quercetin derivatives: 3,7-dimethylquercetin (Compound 80, $[\mathrm{M}+\mathrm{H}]^{+}$at $\mathrm{m} / \mathrm{z}$ 331.0806) and quercetin 3'-O-glucuronide (Compound 69) with $[\mathrm{M}+\mathrm{H}]^{+}$ at $\mathrm{m} / \mathrm{z}$ 479.0802, respectively. Three flavonols derivatives (Compound $75,77,79$ ) were only tentatively characterized in K\&P peel in both positive and negative ionization modes, including kaempferol 3-O-(2"-rhamnosyl-galactoside) 7-O-rhamnoside (Compound 75) with $[\mathrm{M}+\mathrm{H}]^{+}$at m/z 741.2227, myricetin (Compound 77) with $\left[\mathrm{M}-\mathrm{H}^{-}\right.$at $\mathrm{m} / \mathrm{z} 317.0309$ and isorhamnetin 3-O-glucoside 7-O-rhamnoside (Compound 79) with $[\mathrm{M}+\mathrm{H}]^{+}$at m/z 625.1734. Lasano, Hamid, Karim, Dek, Shukri, and Shazini Ramli [25] identified myricetin and some flavonol derivative in mango kernel. Myricetin and kaempferol have been reported to show strong anti-diabetic and anti-oxidant activities [26].

Isoflavonoids Derivatives

In present work, three out of seven different isoflavonoids derivatives (Compound 83, 85, 86) were tentatively identified in two mango peels in both positive and negative ionization modes. Compound (86), showing $[\mathrm{M}+\mathrm{H}]^{+}$at $\mathrm{m} / \mathrm{z} 287.0540$, were tentatively assigned as $3^{\prime}$-hydroxygenistein. Two hydroxyisoflavone derivatives were also present, including 5,6,7,3', $4^{\prime}$-pentahydroxyisoflavone (Compound 85) with $[\mathrm{M}+\mathrm{H}]^{+}$at $\mathrm{m} / \mathrm{z} 303.0482$ and $[\mathrm{M}-\mathrm{H}]^{-}$at $\mathrm{m} / \mathrm{z} 301.0375$, and $3^{\prime}, 4^{\prime}, 5,7-$ tetrahydroxyisoflavanone (Compound 83) with $[\mathrm{M}-\mathrm{H}]^{-}$at $\mathrm{m} / \mathrm{z} 287.0570$. Two isoflavonoids were only found in Keitt peel in $\mathrm{ESI}^{+}$mode $[\mathrm{M}+\mathrm{H}]^{+}$, being tentatively characterized as $2^{\prime}, 7-$ dihydroxy-4',5'-dimethoxyisoflavone (Compound 81) and 6"-O-malonylgenistin (Compound 82). While two isoflavonoids were only identified in K\&P peel in ESI+ mode $[\mathrm{M}+\mathrm{H}]^{+}$, being tentatively characterized as 3'-hydroxydaidzein (Compound 84) and equol 7-O-glucuronide (Compound 87) with $[\mathrm{M}+\mathrm{H}]^{+}$at $\mathrm{m} / \mathrm{z} 271.0612$ and 419.1328 , respectively. Isoflavonoids compounds are commonly found in legumes [29]. To the best of our knowledge, this is the first time that isoflavonoids compounds were identified and characterized in mango fruit.

\section{Other Derivatives of Flavonoid}

Dihydroflavonols was only present in Keitt peel in ESI- mode $[\mathrm{M}-\mathrm{H}]^{-}$, including three compounds tentatively characterized as dihydromyricetin 3-O-rhamnoside (Compound 49), dihydroquercetin 3-O-rhamnoside (Compound 50) and dihydroquercetin (Compound 51). Chalcone was only detected in $\mathrm{K} \& \mathrm{P}$ peel (Compound 48) with $[\mathrm{M}+\mathrm{H}]^{+}$at $\mathrm{m} / \mathrm{z} 355.1542, \mathrm{RT}=77.48 \mathrm{~min}$, which was tentatively characterized as xanthohumol.

\subsubsection{Lignan and Other Polyphenol Derivatives}

Three lignans were detected in both mango peel by-products, including schisantherin A in Keitt peel (Compound 88) and 1-acetoxypinoresinol and schisandrol B in K\&P peel (Compound 89, 90). There were four subtypes of other polyphenols found in the mango peels, including hydroxycoumarins, hydroxyphenylpropenes, tyrosols, and other polyphenols. Hydroxycoumarins and hydroxyphenylpropenes were only detected in K\&P peel and Keitt peel, respectively. To our best knowledge, this is the first report of lignan derivatives identified in mango peel. 
Two other polyphenol derivatives were detected in both peels in positive and negative ionization modes. Compound (97) with $[\mathrm{M}+\mathrm{H}]^{+}$at $\mathrm{m} / \mathrm{z} 171.0641$ was tentatively identified as 3,4-dihydroxyphenylglycol. Compound (98) with $[\mathrm{M}+\mathrm{H}]^{+}$at $\mathrm{m} / \mathrm{z} 127.0382$ and $[\mathrm{M}-\mathrm{H}]^{-}$at $\mathrm{m} / \mathrm{z}$ 125.0250 was tentatively identified as pyrogallol. One hydroxyphenylpropenes was only present in Keitt peel (Compound 93) with $[\mathrm{M}+\mathrm{H}]^{+}$at $\mathrm{m} / \mathrm{z} 149.0952$ and was tentatively identified as anethole, which was previously also identified by Pino, et al. [30] in fifteen different mango cultivars. However, two hydroxycoumarins were only detected in K\&P peel being esculetin (Compound 91 ) with $[\mathrm{M}-\mathrm{H}]^{-}$ at $\mathrm{m} / \mathrm{z}$ 177.0202, and 4-hydroxycoumarin (Compound 92) with $[\mathrm{M}+\mathrm{H}]^{+}$at at $\mathrm{m} / \mathrm{z} 163.0387$.

\subsection{Quantitative Determination of Polyphenols by HPLC-PDA}

The HPLC technique is widely used to separate and quantify the phenolic compounds. Thirteen polyphenols were targeted to quantify through HPLC-PDA, including six phenolic acids (Caffeic acid, chlorogenic acid, gallic acid, $p$-hydroxybenzoic acid, protocatechuic acid, and syringic acid), 7 flavonoids (Catechin, epicatechin gallate, kaempferol, kaempferol-3-glucoside, quercetin, quercetin-3-galactoside, and quercetin-3-glucuronide) based on the LC-ESI-QTOF/MS characterization (Figures S2-S4-Supplementary Materials) and previously reported antioxidant activities.

Table 3 shows the data of the targeted polyphenol compounds in both mango peel samples quantified using HPLC-PDA. Six phenolic acids and six flavonoids were common in both mango peels apart from quercetin-3-glucuronide, which was only detected in Keitt peel extract sample. In the HPLC results, polyphenols were significantly higher in Keitt peel extract as compared to K\&P peel samples. These HPLC results support our previously measured polyphenols (TPC, TFC, and TTC) and antioxidant activities (DPPH, FRAP, and ABTS) while using spectrophotometric assays. Syringic acid, catechin, and quercetin were the most abundant polyphenols quantified in both mango peel samples. Catechin and quercetin have antioxidant, anticancer, anti-inflammatory, anti-aging, and cardio-protection properties [31,32]. Meneses, et al. [33] extracted the polyphenols from mango by-product (mainly mang peel) while using supercritical fluid extraction technique and reported the concentrations of quercetin, quercetin-3-galactoside, and kaempferol in the range of 0.48-0.61, 9.96-11.49, and 0.08-0.11, respectively. Previously, López-Cobo et al. [17] also reported polyphenols from Keitt mango peel, including gallic acid $\left(0.12 \mathrm{mg} / \mathrm{g}_{\text {d.w. }}\right)$, syringic acid $\left(0.07 \mathrm{mg} / \mathrm{g}_{\text {d.w. }}\right)$, catechin $\left(0.11 \mathrm{mg} / \mathrm{g}_{\text {d.w }}\right)$, and quercetin-3-galactoside $\left(0.16 \mathrm{mg} / \mathrm{g}_{\text {d.w. }}\right)$, extracted with $80 \%$ methanol extract. Ribeiro, et al. [34] measured quercetin, quercetin-3-galactoside, and kaempferol-3-glucoside content in Ubá mango peel, which is slightly lower than our reported values. The differences in phenolic contents can be associated with different extraction method and choice of solvents which can effect polyphenol extraction efficiency [35].

$\mathrm{Hu}, \mathrm{Dars}, \mathrm{Liu}, \mathrm{Xie}$, and Sun [18] reported the concentration of gallic acid in different mango peels extracted in the range of $0.08-0.59 \mathrm{mg} / \mathrm{g}$. One of the studies investigated six diffent mango peels and showed that catechin and quercetin-3-galactoside are major polyphenols with concentrations of 252.8 and $242.9 \mu \mathrm{g} / \mathrm{g}_{\text {d.w. }}$, respectively. The study also reported that the content of polyphenols in mango peels significantly decreased during the post-harvest period. During the 6-day post-harvest period, the concentration of catechin and quercetin-3-galactoside reduced $42-93 \%$ and $41-76 \%$, respectively [4]. Overall, the concentrations of phenolic compounds are affected by both the cultivars and maturity level of mango fruit.

The characterization and quantification of polyphenolic compounds showed that some of the polyphenols presented in two mango peel samples have strong antioxidant potential. Hydroxycinnamic acids derivatives, hydroxybenzoic acids and their derivatives, protocatechuic acid, chlorogenic acid, catechin, matairesinol, hydroxytyrosol, quercetin, and kaempferol derivatives are regarded as potential compounds showing considerable free radical scavenging capacity [36-38]. The presence of these antioxidant compounds indicates that mango peel by-products can be good sources of polyphenols and antioxidant potential. In short, both mango peel samples are a good source of polyphenols and could be utilized in food, feed, and pharmaceutical industries. 
Table 3. Quantification of targeted phenolic compounds by high-performance liquid chromatography (HPLC) in mango peels.

\begin{tabular}{|c|c|c|c|c|c|c|c|}
\hline No & Compound Name & Molecular Formula & RT (min) & Standard Equation & Keitt Peel (mg/gd.w.) & K\&P Peel (mg/g $\left.\mathrm{g}_{\text {d.w. }}\right)$ & Polyphenol Class \\
\hline 1 & Gallic acid & $\mathrm{C}_{7} \mathrm{H}_{6} \mathrm{O}_{5}$ & 6.836 & $y=2531.9 x+12238$ & $0.47 \pm 0.02$ & $9.06 \pm 0.01$ & Phenolic acids \\
\hline 2 & Protocatechuic acid & $\mathrm{C}_{7} \mathrm{H}_{6} \mathrm{O}_{4}$ & 12.569 & $y=1824 x-16182$ & $0.31 \pm 0.01$ & $0.28 \pm 0.01$ & Phenolic acids \\
\hline 3 & $p$-Hydroxybenzoic acid & $\mathrm{C}_{7} \mathrm{H}_{6} \mathrm{O}_{3}$ & 20.240 & $y=1387.5 x+5575.1$ & $4.45 \pm 0.03$ & $1.84 \pm 0.01$ & Phenolic acids \\
\hline 4 & Chlorogenic acid & $\mathrm{C}_{16} \mathrm{H}_{18} \mathrm{O}_{9}$ & 20.579 & $y=3043.6 x+4706.3$ & $2.32 \pm 0.01$ & $0.12 \pm 0.02$ & Phenolic acids \\
\hline 5 & Caffeic acid & $\mathrm{C}_{9} \mathrm{H}_{8} \mathrm{O}_{4}$ & 25.001 & $y=5622.4 x+23944$ & $0.14 \pm 0.01$ & $0.05 \pm 0.01$ & Phenolic acids \\
\hline 6 & Syringic acid & $\mathrm{C}_{9} \mathrm{H}_{10} \mathrm{O}_{5}$ & 26.739 & $y=2900.6 x+65091$ & $9.30 \pm 0.01$ & $17.78 \pm 0.01$ & Phenolic acids \\
\hline 7 & Catechin & $\mathrm{C}_{15} \mathrm{H}_{14} \mathrm{O}_{6}$ & 19.704 & $y=779.41 x+2373.3$ & $62.32 \pm 0.01$ & $10.98 \pm 0.01$ & Flavonoids \\
\hline 8 & Epicatechin gallate & $\mathrm{C}_{22} \mathrm{H}_{18} \mathrm{O}_{10}$ & 38.015 & $y=22958 x-26657$ & $0.12 \pm 0.01$ & $0.04 \pm 0.01$ & Flavonoids \\
\hline 9 & Quercetin-3-galactoside & $\mathrm{C}_{21} \mathrm{H}_{20} \mathrm{O}_{12}$ & 40.134 & $y=23472 x+185001$ & $4.09 \pm 0.02$ & $0.23 \pm 0.01$ & Flavonoids \\
\hline 10 & Quercetin-3-glucuronide & $\mathrm{C}_{21} \mathrm{H}_{18} \mathrm{O}_{13}$ & 40.659 & $y=20578 x-36888$ & $0.16 \pm 0.01$ & - & Flavonoids \\
\hline 11 & Kaempferol-3-glucoside & $\mathrm{C}_{21} \mathrm{H}_{20} \mathrm{O}_{11}$ & 47.111 & $y=22405 x-33766$ & $0.38 \pm 0.01$ & $0.28 \pm 0.03$ & Flavonoids \\
\hline 12 & Quercetin & $\mathrm{C}_{15} \mathrm{H}_{10} \mathrm{O}_{7}$ & 70.098 & $y=2585.7 x-29267$ & $39.48 \pm 0.01$ & $1.25 \pm 0.02$ & Flavonoids \\
\hline 13 & Kaempferol & $\mathrm{C}_{15} \mathrm{H}_{10} \mathrm{O}_{6}$ & 80.347 & $y=4425.8 x-110841$ & $2.41 \pm 0.04$ & $0.87 \pm 0.01$ & Flavonoids \\
\hline
\end{tabular}




\section{Conclusions}

Based on the research, it was found that the Keitt peel sample has higher level of phenolic compounds (TPC, TFC, TTC) and higher antioxidant potential (DPPH, FRAP, and ABTS) as compared to the K\&P peel sample. The LC-ESI-QTOF/MS analysis was successfully applied to separate and identify the phenolic profile in the peel of mango Keitt and Kensington Pride. By using this method, a total of 63 and 71 polyphenols were tentatively characterized in K\&P peel and Keitt peel, respectively. Among the identified polyphenols, phenolic acids and flavonoids are the most common polyphenols present in two mango varieties. The HPLC result was also consistent with the result of antioxidant assays, which indicated that Keitt peel could be a good source of antioxidant polyphenols. Moreover, the obtained results could support the commercialization of mango peel by-products as an ingredient of functional food, nutraceuticals, and pharmaceutical development.

Supplementary Materials: The following are available online at http://www.mdpi.com/2227-9717/7/10/764/s1. Table (1S). Phenolic compounds detected and tentatively characterised in Keitt peel extracts by using LC-ESI-QTOF/MS in both positive and negative ionisation modes. Table (2S). Phenolic compounds detected and tentatively characterised in K\&P peel extracts by using LC-ESI-QTOF/MS in both positive and negative ionisation modes. Figure (1S): LC-ESI-QTOF/MS basic peak chromatograph (BPC) for characterization of phenolic compounds of mango peel samples; (a) Keitt peel Base Peak Chromatogram (BPC) in negative ionization mode; (b) Keitt peel BPC in positive ionization mode; (c) K\&P peel BPC in negative ionization mode; (d) K\&P peel BPC in positive ionization mode; (e) A chromatograph of gallic acid (Compound 1, K\&P mango peel extract, Table 2$)$, Retention time $(\mathrm{RT}=6.734)$ in the negative mode of ionization $\left(\mathrm{ESI}-/[\mathrm{M}-\mathrm{H}]^{-}\right)$; (f) Mass spectra of gallic acid showing an observed $m / z$ 169.0150.

Author Contributions: Conceptualization, methodology, validation and investigation, H.A.R.S., F.D., D.P., H.F.Z., S.A.; resources, H.A.R.S. and F.R.D.; writing—original draft preparation, D.P. and H.A.R.S.; writing-review and editing, H.A.R.S., S.A. and F.R.D.; supervision, H.A.R.S. and F.R.D.; funding acquisition, H.A.R.S., K.H. and F.R.D.

Funding: This research was funded by the University of Melbourne under the "McKenzie Fellowship Scheme" and the "Faculty Research Initiative Funds" funded by the Faculty of Veterinary and Agricultural Sciences, The University of Melbourne, Australia.

Acknowledgments: We would like to thank Nicholas Williamson, Shuai Nie and Michael Leeming from the Mass Spectrometry and Proteomics Facility, Bio21 Molecular Science and Biotechnology Institute, The University of Melbourne, VIC, Australia for providing access and support for the use of HPLC and LC-QTOF-ESI/MS and data analysis. We would also like to thank for Kate Howell, Chunhe Gu, Rana Dildar Khan, Chao Ma, Jiafei Tang, Biming Zhong, Yuying Feng, Danwei Yang and Yasir Iqbal from the School of Agriculture and Food, Faculty of Veterinary and Agricultural Sciences, The University of Melbourne for their incredible support.

Conflicts of Interest: The authors declare no conflict of interest.

\section{References}

1. FAO. Value of Agricultural Production; Food and Agriculture Ognization of the United Nations: Rome, Italy, 2018.

2. Ajila, C.M.; Naidu, K.A.; Bhat, S.G.; Rao, U.J.S.P. Bioactive compounds and antioxidant potential of mango peel extract. Food Chem. 2007, 105, 982-988. [CrossRef]

3. Iqbal, M.; Saeed, A.; Zafar, S.I. FTIR spectrophotometry, kinetics and adsorption isotherms modeling, ion exchange, and EDX analysis for understanding the mechanism of $\mathrm{Cd} 2+$ and $\mathrm{Pb} 2+$ removal by mango peel waste. J. Hazard. Mater. 2009, 164, 161-171. [CrossRef] [PubMed]

4. Monribot-Villanueva, J.L.; Elizalde-Contreras, J.M.; Aluja, M.; Segura-Cabrera, A.; Birke, A.; Guerrero-Analco, J.A.; Ruiz-May, E. Endorsing and extending the repertory of nutraceutical and antioxidant sources in mangoes during postharvest shelf life. Food Chem. 2019, 285, 119-129. [CrossRef] [PubMed]

5. Naczk, M.; Shahidi, F. Phenolics in cereals, fruits and vegetables: Occurrence, extraction and analysis. J. Pharm. Biomed. Anal. 2006, 41, 1523-1542. [CrossRef]

6. Farrés-Cebrián, M.; Seró, R.; Saurina, J.; Núñez, O. HPLC-UV polyphenolic profiles in the classification of olive oils and other vegetable oils via principal component analysis. Separations 2016, 3, 33. [CrossRef]

7. Shahidi, F.; Zhong, Y. Measurement of antioxidant activity. J. Funct. Foods 2015, 18, 757-781. [CrossRef] 
8. Dorta, E.; González, M.; Lobo, M.G.; Sánchez-Moreno, C.; de Ancos, B. Screening of phenolic compounds in by-product extracts from mangoes (Mangifera indica L.) by HPLC-ESI-QTOF-MS and multivariate analysis for use as a food ingredient. Food Res. Int. 2014, 57, 51-60. [CrossRef]

9. Pierson, J.T.; Monteith, G.R.; Roberts-Thomson, S.J.; Dietzgen, R.G.; Gidley, M.J.; Shaw, P.N. Phytochemical extraction, characterisation and comparative distribution across four mango (Mangifera indica L.) fruit varieties. Food Chem. 2014, 149, 253-263. [CrossRef]

10. Gu, C.; Howell, K.; Dunshea, F.R.; Suleria, H.A.R. LC-ESI-QTOF/MS characterisation of phenolic acids and flavonoids in polyphenol-rich fruits and vegetables and their potential antioxidant activities. Antioxidants 2019, 8, 405. [CrossRef]

11. Severo, J.; Tiecher, A.; Chaves, F.C.; Silva, J.A.; Rombaldi, C.V. Gene transcript accumulation associated with physiological and chemical changes during developmental stages of strawberry cv. Camarosa. Food Chem. 2011, 126, 995-1000. [CrossRef]

12. Lamien-Meda, A.; Lamien, C.; Compaoré, M.; Meda, R.; Kiendrebeogo, M.; Zeba, B.; Millogo, J.; Nacoulma, O. Polyphenol content and antioxidant activity of fourteen wild edible fruits from burkina faso. Molecules 2008, 13, 581-594. [CrossRef] [PubMed]

13. Rebaya, A.; Belghith, S.I.; Baghdikian, B.; Leddet, V.M.; Mabrouki, F.; Olivier, E.; Cherif, J.; Ayadi, M.T. Total phenolic, total flavonoid, tannin content, and antioxidant capacity of halimium halimifolium (cistaceae). J. Appl. Pharm. Sci. 2014, 5, 52-57.

14. Sogi, D.S.; Siddiq, M.; Greiby, I.; Dolan, K.D. Total phenolics, antioxidant activity, and functional properties of 'tommy atkins' mango peel and kernel as affected by drying methods. Food Chem. 2013, 141, 2649-2655. [CrossRef] [PubMed]

15. Dorta, E.; Lobo, M.G.; González, M. Using drying treatments to stabilise mango peel and seed: Effect on antioxidant activity. LWT Food Sci. Technol. 2012, 45, 261-268. [CrossRef]

16. Molyneux, P. The use of the stable free radical diphenylpicrylhydrazyl (DPPH) for estimating antioxidant activity. Songklanakarin J. Sci. Technol. 2004, 26, 211-219.

17. López-Cobo, A.; Verardo, V.; Diaz-de-Cerio, E.; Segura-Carretero, A.; Fernández-Gutiérrez, A.; Gómez-Caravaca, A.M. Use of HPLC- and GC-QTOF to determine hydrophilic and lipophilic phenols in mango fruit (Mangifera indica L.) and its by-products. Food Res. Int. 2017, 100, 423-434.

18. Hu, K.; Dars, A.G.; Liu, Q.; Xie, B.; Sun, Z. Phytochemical profiling of the ripening of chinese mango (Mangifera indica L.) cultivars by real-time monitoring using UPLC-ESI-QTOF-MS and its potential benefits as prebiotic ingredients. Food Chem. 2018, 256, 171-180. [CrossRef]

19. Ajila, C.M.; Jaganmohan Rao, L.; Prasada Rao, U.J.S. Characterization of bioactive compounds from raw and ripe Mangifera indica L. Peel extracts. Food Chem. Toxicol. 2010, 48, 3406-3411. [CrossRef]

20. Abdalla, A.E.; Darwish, S.M.; Ayad, E.H.; El-Hamahmy, R.M. Egyptian mango by-product 1. Compositional quality of mango seed kernel. Food Chem. 2007, 103, 1134-1140. [CrossRef]

21. Kim, Y.; Brecht, J.K.; Talcott, S.T. Antioxidant phytochemical and fruit quality changes in mango (Mangifera indica L.) following hot water immersion and controlled atmosphere storage. Food Chem. 2007, 105, 1327-1334. [CrossRef]

22. Belščak-Cvitanović, A.; Durgo, K.; Huđek, A.; Bačun-Družina, V.; Komes, D. 1-Overview of polyphenols and their properties. In Polyphenols: Properties, Recovery, and Applications; Galanakis, C.M., Ed.; Woodhead Publishing: Sawston, UK, 2018; pp. 3-44.

23. Berardini, N.; Fezer, R.; Conrad, J.; Beifuss, U.; Carle, R.; Schieber, A. Screening of mango (Mangifera indica L.) cultivars for their contents of flavonol O-and Xanthone C-Glycosides, anthocyanins, and Pectin. J. Agric. Food Chem. 2005, 53, 1563-1570. [CrossRef] [PubMed]

24. Karanjalker, G.R.; Ravishankar, K.V.; Shivashankara, K.S.; Dinesh, M.R.; Roy, T.K.; Sudhakar Rao, D.V. A study on the expression of genes involved in carotenoids and anthocyanins during ripening in fruit peel of green, yellow, and red colored mango cultivars. Appl. Biochem. Biotechnol. 2018, 184, 140-154. [CrossRef] [PubMed]

25. Lasano, N.F.; Hamid, A.H.; Karim, R.; Dek, M.S.P.; Shukri, R.; Shazini Ramli, N. Nutritional composition, anti-diabetic properties and identification of active compounds using UHPLC-ESI-orbitrap-MS/MS in Mangifera odorata L. Peel and seed kernel. Molecules 2019, 24, 320. [CrossRef] [PubMed]

26. Wang, H.; Du, Y.-J.; Song, H.-C. A-glucosidase and $\alpha$-amylase inhibitory activities of guava leaves. Food Chem. 2010, 123, 6-13. [CrossRef] 
27. Masibo, M.; He, Q. Major mango polyphenols and their potential significance to human health. Compr. Rev. Food Sci. Food Saf. 2008, 7, 309-319. [CrossRef]

28. Schieber, A.; Ullrich, W.; Carle, R. Characterization of polyphenols in mango puree concentrate by HPLC with diode array and mass spectrometric detection. Innov. Food Sci. Emerg. Technol. 2000, 1, 161-166. [CrossRef]

29. Lattanzio, V. Bioactive polyphenols: Their role in quality and storability of fruit and vegetables. J. Appl. Bot. 2003, 77, 128-146.

30. Pino, J.A.; Mesa, J.; Munoz, Y.; Martí, M.P.; Marbot, R. Volatile components from mango (Mangifera indica L.) cultivars. J. Agric. Food Chem. 2005, 53, 2213-2223. [CrossRef]

31. Boots, A.W.; Haenen, G.R.M.M.; Bast, A. Health effects of quercetin: From antioxidant to nutraceutical. Eur. J. Pharmacol. 2008, 585, 325-337. [CrossRef]

32. Zanwar, A.A.; Badole, S.L.; Shende, P.S.; Hegde, M.V.; Bodhankar, S.L. Chapter 21-Antioxidant role of catechin in health and disease. In Polyphenols in Human Health and Disease; Watson, R.R., Preedy, V.R., Zibadi, S., Eds.; Academic Press: San Diego, CA, USA, 2014; pp. 267-271.

33. Meneses, M.A.; Caputo, G.; Scognamiglio, M.; Reverchon, E.; Adami, R. Antioxidant phenolic compounds recovery from Mangifera indica L. By-products by supercritical antisolvent extraction. J. Food Eng. 2015, 163, 45-53. [CrossRef]

34. Ribeiro, S.; Barbosa, L.; Queiroz, J.; Knödler, M.; Schieber, A. Phenolic compounds and antioxidant capacity of brazilian mango (Mangifera indica L.) varieties. Food Chem. 2008, 110, 620-626. [CrossRef]

35. Ismail, B.B.; Pu, Y.; Guo, M.; Ma, X.; Liu, D. Lc-ms/qtof identification of phytochemicals and the effects of solvents on phenolic constituents and antioxidant activity of baobab (adansonia digitata) fruit pulp. Food Chem. 2019, 277, 279-288. [CrossRef] [PubMed]

36. Grzesik, M.; Naparlo, K.; Bartosz, G.; Sadowska-Bartosz, I. Antioxidant properties of catechins: Comparison with other antioxidants. Food Chem. 2018, 241, 480-492. [CrossRef] [PubMed]

37. Martínez, L.; Ros, G.; Nieto, G. Hydroxytyrosol: Health benefits and use as functional ingredient in meat. Medicines 2018, 5, 13. [CrossRef]

38. Shang, Y.; Liu, B.; Zhao, M. Details of the antioxidant mechanism of hydroxycinnamic acids. Czech J. Food Sci. 2016, 33, 210-216. [CrossRef]

(C) 2019 by the authors. Licensee MDPI, Basel, Switzerland. This article is an open access article distributed under the terms and conditions of the Creative Commons Attribution (CC BY) license (http://creativecommons.org/licenses/by/4.0/). 